\title{
Kredi Derecelendirmenin Borsa Endeksleri Üzerindeki Etkileri: T-BRICS Ülkeleri Üzerine Bir Araştırma*
}

\author{
Musa OVALI**
}

\author{
Turan KOCABIYIK ${ }^{* * *}$
}

\begin{abstract}
$\ddot{O} Z$
Bu çalışmanın amacı derecelendirme kuruluşları tarafindan verilen ülke derecelendirme notlarının ülkelerin borsa endeksleri üzerindeki etkilerini ortaya koymaktır. Bu amaçla, S\&P, Moody's ve Fitch derecelendirme kuruluşlar tarafindan 2004-2019 ylları arasinda T-BRICS ülkelerine verilen derecelendirme notlarının hisse senedi piyasaları üzerine etkileri olay çalışması yöntemiyle incelenmiştir. Anormal getirilerin varlığı, olayın etkilerini açık bir şekilde ortaya koyabilmek amacıyla $\pm 15, \pm 10, \pm 5$ ve \pm 1 günlük olay pencereleri dahilinde incelenmiştir. Analiz sonucunda bazı ülkelerin borsa endekslerinde negatif (pozitif) olayla aynı yönde negatif (pozitif) anormal getiriler tespit edilmiştir. Ek olarak bazı ülkelerin ise coğrafi konumları itibartyla aynı olaylar karşısında farklı tepkiler verebildiği sonucuna ulaşılmıştır. Analiz sonucunda not duyurularının istatistiki olarak anlaml kümülatif anormal getiri, ortalama anormal getiri ve kümülatif ortalama anormal getiriye yol açtığı tespit edilmiş, ilgili ülkelerdeki mevcut piyasaların yarl-etkin piyasa formunda etkin olmadı̆̆ı sonucuna ulaşılmışıtır.
\end{abstract}

Anahtar Kelimeler: Kredi Derecelendirme, Ülke Kredi Derecelendirme, T-BRICS, Olay Çalışması, Anormal Getiri, Kümülatif Anormal Getiri.

JEL Sinıflandırması: G14, G24, N20

\section{The Impacts Of Credit Ratings On Stock Exchanges: A Research On T-BRICS Countries}

\begin{abstract}
The aim of this study is to reveal the effects of sovereign credit ratings given by the rating agencies on the stock exchanges of the countries. For this purpose, the effects of the ratings given by $S \& P$, Moody's and Fitch rating institutions for T-BRICS countries stock markets have been investigated by event study method between 2004-2019. The presence of abnormal returns have been examined within $\pm 15, \pm 10, \pm 5$ and \pm 1 day event windows in order to clearly demonstrate the effects of the event. As a result of the analysis, it has been found that negative (positive) event in the same direction of negative (positive) abnormal return in the stock exchanges of some countries. In addition, it has been concluded that some countries may react differently to the same events due to their geographical location. Finally it has been concluded that sovereign credit rating announcements caused statistically significant cumulative abnormal returns, average abnormal
\end{abstract}

\footnotetext{
* Bu çalışma Süleyman Demirel Üniversitesi, SBE, İşletme ABD’nda 2019 y1lında sunulan "Ülke Kredi Derecelendirmesi ve Borsa Endeksleri Üzerine Etkisi: T-BRICS Ülkeleri Örneği" başlıklı yüksek lisans tezinden türetilmiştir. Aynı zamanda tez kitap olarak da basılmıştır.

** Araş. Gör., Manisa Celal Bayar Üniversitesi, İşletme Fakültesi İşletme Bölümü, musa.ovali@cbu.edu.tr ORCID: 0000-0001-6678-9719

**** Dr. Öğr. Üyesi, Süleyman Demirel Üniversitesi, İïBF Bankacılık ve Finans Bölümü, turankocabiyik@sdu.edu.tr ORCID: 0000-0003-3651-206X

${ }_{* * * *}^{*}$ Doç. Dr., Manisa Celal Bayar Üniversitesi, İşletme Fakültesi İșletme Bölümü, umutburak.geyikci@cbu.edu.tr ORCID: 0000-0002-4285-2151
} 
Musa Ovalı \& Turan Kocablyık \& Umut Burak Geyikçi / Kredi Derecelendirmenin Borsa Endeksleri Üzerindeki Etkileri: T-BRICS Ülkeleri Üzerine Bir Araştırma

returns and cumulative average abnormal returns, consequently the current markets in the relevant countries were not semi-strong form efficiency.

Key Words: Credit Rating, Sovereign Credit Rating, T-BRICS, Event Study, Abnormal Return, Cumulative Abnormal Return.

JEL Classification: G14, G24, N20

\section{GİRİş}

Son yıllarda finans piyasalarında globalleşmeyle meydana gelen gelişmeler bu piyasalardaki finansal enstrüman sayısının artmasına ve çeşitlenmesine neden olmuştur. Fon talep eden ve fon arz edenler, fon kaynağ bulma ve yatırım kararı alma konularında ciddi sorunlarla karşılaşmışlardır. Fon arz edenler asimetrik bilgi sorununu ortadan kaldırmak, fon talep edenler ise yatırımcı güvenini kazanmak amacıyla kredi derecelendirme kuruluşlarına (KDK) yönelmişlerdir. Kredi derecelendirme, fon talep edenler ve fon arz edenler arasında karar alma sürecini kolaylaştıran bir bilgi kaynağı olarak görülmektedir. Derecelendirme faaliyetini yürüten KDK'lar ise, finansal kurum ve kuruluşların, firmaların ve ülkelerin k1sacası finansal piyasa katılımcılarının kısa ve uzun vadeli yükümlülüklerini (anapara ve faiz) yerine getirme potansiyelinin değerlendirilmesini ve sınıflandırılmasını bağımsız, tarafsız ve adil olarak yapan kuruluşlardır (Hunt, 2009;SPK, 2017).

Baş döndürücü hızda gelişen teknolojiyle birlikte finansal piyasaların globalleşme ile hız kazanması ve global rekabetin gün geçtikçe artması, kredi derecelendirmelerinin ABD dışındaki ülkelerdeki rolünü arttırmıştır (Kocabıyık \& Altunay, 2008;SEC, 2003). Partony (1999) derecelendirme faaliyetlerinin piyasada artan rolü ve başarısını piyasa düzenleyicilerinin derecelendirmeye olan bağımlılıklarının bir sonucu olduğunu ifade etmiştir. Tüm kuruluşlar arasında kamuoyu tarafından kabul edilmiş en güvenilir ve popüler kuruluşlar Standard \& Poor's, Fitch ve Moody's uluslararası derecelendirme kuruluşlarıdır. Bu üç kuruluşun faaliyetleri derecelendirme piyasasının \%95'lik kısmını oluşturduğundan literatürde muhteşem üçlü olarak anılmaya başlanmışlardır (CFR,15.02.2019).

Tahvil ve sermaye piyasaları global ölçekte yaklaşık iki asırdır faaliyette bulunmalarına rağmen KDK'ların bu piyasalarda faaliyet gösteren kuruluşları ciddi anlamda derecelendirmesi 20.yy başlarına dayanmaktadır (Geyikçi \& Karğın, 2014:324). Kuruluşları sürekli olarak izleme faaliyetleri KDK'lara borçlanma araçları ihraç edenler hakkında özel bilgilere erişebilme imkânı sağlamaktadır. Dolayısıyla bu kuruluşlar piyasa katılımcılarından daha fazla bilgi avantajina sahiptirler (Caselli vd., 2016: 144). Bu nedenle KDK'lar piyasada önemli etkileri olan kuruluşlardır. Bu etkiler özellikle bir firmaya ya da ülkeye ilişkin yapılacak derecelendirme duyurusu, not görünümünde bir değişiklik içeriyorsa yatırımcıların alacağ kararlarda hızlı değişmelerle ortaya çıkmaktadır (Norden \& Weber, 2004: 2814). Derecelendirilen kurum ya da kuruluş hakkındaki görüşleri ifade eden notlar ve anlamları Tablo 1'de verilmiştir. 
Tablo 1. Uzun Vadeli Not Düzeyleri ve Anlamları

\begin{tabular}{|c|c|c|c|c|}
\hline \multicolumn{2}{|c|}{ Not Anlamları } & FITCH & MOODY'S & S\&P \\
\hline \multirow{10}{*}{$\begin{array}{c}\text { Yatırım } \\
\text { Yapılabilir Seviye }\end{array}$} & Prime & AAA & Aaa & AAA \\
\hline & \multirow{3}{*}{ Üst Seviye } & $\mathrm{AA}+$ & Aa1 & $\mathrm{AA}+$ \\
\hline & & AA & $\mathrm{Aa} 2$ & AA \\
\hline & & AA- & Aa3 & AA- \\
\hline & \multirow{3}{*}{ Üst - Orta Seviye } & $\mathrm{A}+$ & A1 & $\mathrm{A}+$ \\
\hline & & $\mathrm{A}$ & $\mathrm{A} 2$ & $\mathrm{~A}$ \\
\hline & & A- & A3 & A- \\
\hline & \multirow{3}{*}{ Alt - Orta Seviye } & $\mathrm{BBB}+$ & Baa1 & $\mathrm{BBB}+$ \\
\hline & & $\mathrm{BBB}$ & $\mathrm{Baa} 2$ & BBB \\
\hline & & BBB- & Baa3 & BBB- \\
\hline \multirow{3}{*}{ Spekülatif Seviye } & \multirow{3}{*}{$\begin{array}{c}\text { Yatırım Yapılamaz- } \\
\text { Spekülatif }\end{array}$} & $\mathrm{BB}+$ & $\mathrm{Ba} 1$ & $\mathrm{BB}+$ \\
\hline & & $\mathrm{BB}$ & $\mathrm{Ba} 2$ & BB \\
\hline & & BB- & $\mathrm{Ba} 3$ & BB- \\
\hline \multirow{8}{*}{ Düşük Seviye } & \multirow{3}{*}{ Oldukça Spekülatif } & $\mathrm{B}+$ & B1 & $\mathrm{B}+$ \\
\hline & & $\mathrm{B}$ & $\mathrm{B} 2$ & $\mathrm{~B}$ \\
\hline & & B- & B3 & B- \\
\hline & Önemli Riskler & $\mathrm{CCC}+$ & Caa1 & $\mathrm{CCC}+$ \\
\hline & $\begin{array}{c}\text { Aşırı Spekülatif } \\
\text { Riskler }\end{array}$ & $\mathrm{CCC}$ & $\mathrm{Caa} 2$ & $\mathrm{CCC}$ \\
\hline & İflas Eşiği & CCC- & Caa3 & CCC- \\
\hline & \multirow[b]{2}{*}{ İflas, Batık } & $\mathrm{C}$ & $\mathrm{Ca}$ & $\mathrm{C}$ \\
\hline & & $\mathrm{D}$ & $\mathrm{C}$ & $\mathrm{D}$ \\
\hline
\end{tabular}

Kaynak: (TCMB, 12.02.2019)

Tablo 1'de yer alan derecelendirme notları ülkeler açısından ele alınacak olursa, ülkelerin finansal yükümlülüklerini yerine getirme kabiliyetlerinin temel bir göstergesidir. Ayrıca ülkeler için derecelendirme notları; ülkenin politik, ekonomik ve toplumsal durumu göz önünde bulundurularak belirlenen ülke kredibilitesi hakkında bilgi veren derecelendirme görüşünü ifade etmektedir. $\mathrm{Bu}$ notlar aynı zamanda yatırım ve tasarruf miktarlarının da önemli belirleyicilerindendir. Globalleşmeyle uluslararası yatırımların bir ülkeden diğerine akışı mümkün hale gelmiş, bu durum bir ülke borsasındaki yatırımını sonlandıran yatırımcının bir başka ülkeye ait alternatif hisse senedi piyasasına yönelmesine imkan tanımıştır. $\quad \mathrm{Bu}$ da yatırımın yönlendirildiği ülkenin gelişmesine katkı sağlamıştır. Yatırımlar ekonomik büyümenin kaynağı olarak görüldügünden iyi bir derece notu yatırımların artmasına dolayısıyla ekonomik büyümenin de önünün açılmasına olanak sağlayacaktır (Ovalı, 2014; Kocabıyık, 2015).

T-BRICS ülkeleri: Türkiye, Brezilya, Rusya, Hindistan, Çin ve G.Afrika'dır. Bu gruplandırma, ilk kez 2001 yılında Jim O’Neill tarafından BRIC olarak ortaya atılmıştır ${ }^{1}$.

\footnotetext{
${ }^{1}$ Goldman Sachs Yönetim Kurulu Başkanı olan O’neill tarafindan Building Better Global Economic BRICs isimli raporla ortaya çıkan BRIC sınıflandırmasına 24 Kasım 2010 tarihinde G.Afrika'da eklenerek BRICS olarak devam edilmiştir. Türkiye'nin bu gruba katılması için girişimlerde bulunulsa da bu resmi olarak gerçekleşmemiştir. Ancak Temmuz 2018 tarihinde yapılan BRICS zirvesine Türkiye özel davetli olarak katılım sağlayarak birliğe girme konusunda gelişme kaydetmiştir.
} 
Çalışmanın önemi, global ekonomideki konumları, nüfus yapıları, yüzölçümleri ve gelecekte Dünya'nın lider ekonomilerinden olma potansiyeline sahip olmaları nedeniyle T-BRICS ülkelerinin hisse senedi piyasalarının etkinliklerinin araştıılması noktasında ortaya çıkmaktadır. T-BRICS ülkelerinin hisse senedi piyasalarının yatırımcılara ve doğrudan yabancı yatırımlara karşı güven vermesi, sermayeye erişim noktasında kolaylığa ve edinim maliyetleri üzerinde oldukça olumlu etkiye sebep olacaktır. Yatırımcının bu piyasalara olan güveni, ülkelerin derecelendirme notları, hisse senedi piyasalarının derecelendirme not duyurularını ne zaman fiyatladıkları ve piyasa etkinliği ile doğrudan alakalıdır.

\section{LITERATÜR TARAMASI}

Derecelendirme duyurularının finansal piyasalar üzerindeki etkisi, son dönem literatüründe finans çevrelerinin ilgisini çeken bir konu olarak ortaya çıkmaktadır. Kredi derecelendirmeyi konu alan çalışmalardan Griffin ve Sanvicente (1982) 1960-1975 yılları arasında derecelendirme not değişikliklerinin hisse senedi piyasaları üzerindeki etkilerini piyasa modeliyle incelemişlerdir. Hisse senedi piyasasının not düşüşüne tepki verdiği ancak not artışlarının fiyatlama üzerinde herhangi bir etkiye neden olmadığını tespit etmişlerdir. Liu ve Thakor (1984) ile Ederington, Yawitz ve Roberts (1987) özellikle kurumsal derecelendirmeleri kar marjlarına etki eden değişkenler olarak değerlendirerek etkilerini araştıran çalışmalar olarak ortaya çıkmaktadır. Yıllar itibarıyla derecelendirme faaliyetlerinin finansal piyasalar üzerine etkilerini ele alan çalışmalara Tablo 2'de yer verilmiştir.

Tablo 2. Derecelendirme Not Duyurularının Hisse Senedi Piyasaları Üzerine Etkisini

Konu Alan Çalışmalar

\begin{tabular}{|c|c|c|}
\hline Çalıșma & Veri ve Yöntem & Sonuç \\
\hline $\begin{array}{c}\text { Reisen ve von Maltzan } \\
\text { (1998) }\end{array}$ & $\begin{array}{l}\text { 1987-1996 yılları arasında ülke } \\
\text { derecelendirme duyurularının } \\
\text { devlet tahvilleri ve hisse senedi } \\
\text { piyasaları üzerindeki etkilerini } \\
\text { olay çalışması yöntemiyle } \\
\text { incelemişlerdir. }\end{array}$ & 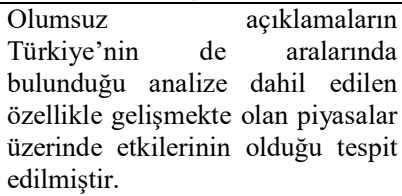 \\
\hline $\begin{array}{l}\text { Kaminsky ve Schmukler } \\
\text { (2002) }\end{array}$ & $\begin{array}{l}\text { 1990-2000 yılları arasından S\&P, } \\
\text { Moody's ve Fitch tarafindan } 16 \\
\text { gelişmekte olan ülke için yapılan } \\
\text { not ve bildirim duyurularının } \\
\text { ülkelerin hisse senedi ve tahvil } \\
\text { piyasalarına etkisini olay çalışması } \\
\text { ve panel veri analiziyle } \\
\text { incelemișlerdir. }\end{array}$ & $\begin{array}{l}\text { Derecelendirme ve görünüm } \\
\text { değişikliklerinin tahvil ve hisse } \\
\text { senedi piyasalarını önemli ölçüde } \\
\text { etkilediği sonucuna ulaşmışlardır. }\end{array}$ \\
\hline \multirow[t]{2}{*}{$\begin{array}{l}\text { Brooks vd. } \\
\text { (2004) }\end{array}$} & $\begin{array}{l}\text { S\&P, Moody's, Fitch ve Thomson } \\
\text { tarafindan 1973-2001 yılları } \\
\text { arasında ülke notlarının hisse } \\
\text { senedi piyasaları üzerine etkilerini } \\
\text { olay çalışması yöntemiyle [- } \\
\text { 10;+10] aralığında incelemişlerdir. }\end{array}$ & $\begin{array}{l}\text { Sadece not düşürümlerinin piyasa } \\
\text { getirisi üzerinde fiyat etkisin } \\
\text { bulunduğunu, not artışlarının } \\
\text { anlamlı etkiye sahip olmadığını } \\
\text { tespit etmişlerdir. }\end{array}$ \\
\hline & $\begin{array}{ll}\text { Çalışmada } & \text { Moody's ve } \text { Fitch } \\
\text { tarafindan } & 1995-2007 \quad \text { arasında }\end{array}$ & $\begin{array}{l}\text { Analiz sonucunda not düşüşlerinin } \\
\text { piyasa getirisi üzerinde zayıf }\end{array}$ \\
\hline
\end{tabular}




\begin{tabular}{|c|c|c|}
\hline $\begin{array}{c}\text { Feride Öztürk Subaş1 } \\
\text { (2008) }\end{array}$ & $\begin{array}{llr}\text { Türkiye için verilen } & \text { ülke derece } \\
\text { notları ve } & \text { görünüm } \\
\text { değişikliklerinin } & \text { IMKB-100 } \\
\text { üzerine etkisi olay } & \text { çalışması } 1 \\
\text { yöntemiyle }[-5 ;+5] & \text { aralığında } \\
\text { incelemistir } & \end{array}$ & 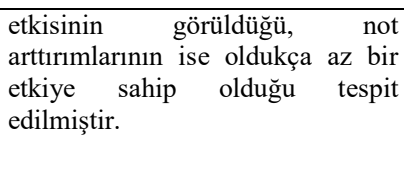 \\
\hline$\underset{\text { Klimavičienè }}{\text { Klo }}$ & 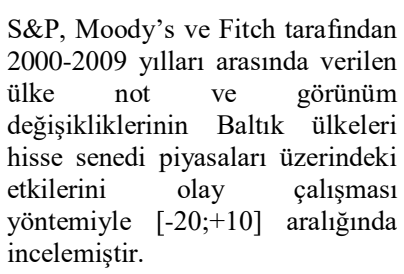 & $\begin{array}{lcr}\text { Analiz } & \text { sonucunda } & \text { olumsuz } \\
\text { olayların } & \text { fiyat } & \text { etkisinin } \\
\text { olumlulardan daha büyük olduğu } \\
\text { tespit edilmiştir. }\end{array}$ \\
\hline $\begin{array}{l}\text { Alsakka ve Gwilym } \\
\qquad \text { (2012) }\end{array}$ & $\begin{array}{l}\text { S\&P, Moody's ve Fitch tarafindan } \\
1994-2010 \text { yılları arasında } 124 \\
\text { gelişmiş ve gelişsmekte olan ülkeyi } \\
\text { kapsayan not duyurularının } \\
\text { ülkelere ait döviz spot piyasalarına } \\
\text { etkilerini olay çalışmas1 } \\
\text { yöntemiyle incelemişlerdir. } \\
\text { Çalışmada olay penceresi [-1:+30] } \\
\text { arasında belirlenmiş ve } \\
\text { derecelendirme olaylarının } \\
\text { piyasalara etkisi [-1;+1], [-1;+3], } \\
{[-1 ;+7],[-1 ;+14],[-1 ;+30] \text { olmak }} \\
\text { üzere 5 aralıkta incelenmiştir }\end{array}$ & $\begin{array}{l}\text { İnceleme sonucu pozitif ve negatif } \\
\text { derecelendirme duyurularını } \\
\text { ülkelerin döviz kurlarını etkilediği } \\
\text { sonucuna ulaşılmıştr. Gelişmekte } \\
\text { olan ülkelerde ve çeşitli coğrafi } \\
\text { bölgelerde ülke derecelendirme } \\
\text { not duyurularına verilen piyasa } \\
\text { tepkilerinde gözle görülür } \\
\text { farklılıklar tespit edilmiştir. }\end{array}$ \\
\hline $\begin{array}{l}\text { Paterson ve Gauthier } \\
\qquad \text { (2013) }\end{array}$ & $\begin{array}{l}2009-2013 \text { tarihleri arasında } \\
\text { meydana gelen ülke } \\
\text { derecelendirme not duyurularının } \\
\text { GIIPS ve BRIC ülkeleri ulusal } \\
\text { hisse senedi piyasaları üzerindeki } \\
\text { etkileri olay çalışması yöntemiyle } \\
\text { incelemişlerdir }\end{array}$ & $\begin{array}{l}\text { Not düşüşlerinin GIIPS ülkeleri } \\
\text { için negatif kümülatif anormal } \\
\text { getiriyle sonuçlandığ } 1 \text { dolayısiyla } \\
\text { piyasalar üzerinde etkisinin } \\
\text { olduğu, BRIC ülkeleri için ise artış } \\
\text { ve azalışların herhangi bir anormal } \\
\text { getiriye yol açmadığ } 1 \text { tespit } \\
\text { edilmiştir. }\end{array}$ \\
\hline $\begin{array}{l}\text { Burak Pirgaip } \\
\quad \text { (2017) }\end{array}$ & $\begin{array}{l}\text { Çalışmada S\&P, Fitch ve Moody's } \\
\text { tarafindan 1993-2016 yilları } \\
\text { arasinda Türkiye için verilen ülke } \\
\text { derece not değişikliklerinin BIST } \\
\text { üzerine etkilerini olay çalışmas } \\
\text { yöntemiyle [-10;+10] olay } \\
\text { penceresinde incelemiştir. }\end{array}$ & $\begin{array}{l}\text { Olumsuz not değişikliklerinin } \\
\text { piyasa getirileri } \text { üzerindeki } \\
\text { etkilerinin olumlu değişikliklere } \\
\text { kiyasla daha fazla olduğu tespit } \\
\text { edilmiştir. }\end{array}$ \\
\hline $\begin{array}{l}\text { Coşkun } \\
\text { (2018) }\end{array}$ & $\begin{array}{l}\text { Çalışmada S\&P, Fitch ve Moody's } \\
\text { tarafindan verilen ülke notlarında } \\
\text { meydana gelen değişimin hisse } \\
\text { senedi piyasası endeks getirileri } \\
\text { üzerine etkisi olay çalışası } \\
\text { yöntemiyle } \\
\text { penceresinde incelemiștir. }\end{array}$ & $\begin{array}{l}\text { Ülke notunda artı̧ meydana } \\
\text { geldiğinde endekslerde elde edilen } \\
\text { anormal getiri miktarı ülke } \\
\text { notunda düşüş meydana geldiğine } \\
\text { kiyasla daha fazla gerçekleşmiştir. }\end{array}$ \\
\hline
\end{tabular}

\section{ARAŞTIRMANIN VERİ SETI VE YÖNTEMI}

Çalışmada S\&P, Moody's ve Fitch tarafından T-BRICS ülkeleri için verilen ülke notları ve bu notlardaki değişimlerin ilgili 6 ülkenin hisse senedi piyasaları üzerindeki etkileri olay çalışması yöntemiyle incelenmiştir. Analiz 
dönemi olarak 2004-2019 yılları belirlenmiştir. Bu analiz dönemi, 2008 öncesi dönem (2004-2008) ve 2008 sonrası dönem (2008-2019) olarak ikiye ayrılmıştır. Analiz döneminin 2008 tarihinden öncesi ve sonrası olarak ele alınmasının sebebi, bu tarihte ABD'de Mortgage krizinin meydana gelmesiyle dünya ekonomisinde ve özellikle gelişmekte olan ülkeler üzerinde oldukça etkileyen bir olay olma özelliğindendir. Araştırmaya konu ülkeler ve hisse senedi piyasaları Türkiye (BİST100), Brezilya (BOVESPA), Rusya (IMOEX), Hindistan (NIFTY50), Çin (SHANGHAI COMPOSITE) ve G.Afrika (FTSE/JSE ALL SHARE) olarak belirlenmiştir.

Uluslararası yatırımcıların önemli düzeyde işlem yaptığı piyasalarda yatırımcılar ve analistler varlık fiyatlarını ve getirilerini yerel para birimleri ile incelemekle birlikte aynı zamanda konvertibl para birimleri cinsinden de incelemektedir. $\mathrm{Bu}$ değerlendirme, yabancı yatırımcılara elde ettikleri getirileri kendi ülkelerindeki veya başka ülkelerdeki alternatif yatırım araçları ile karşılaştırma imkânı sunmaktadır. Ayrıca, zaman serilerine dayanan çalışmalarda değişkenlerin ortak bir para birimi cinsinden analize dahil edilebilmesi tüm değişkenlerin ortak bir paydada buluşturulmasını sağlayacaktır. Park (2004) yaptığı çalışmada endekslerin dolar cinsinden değerini bulurken yabancı paraların ticaret ağırlıklı ABD doları fiyatını kullanmıştır. Diğer taraftan veri setinde bulunan değerler, para birimi ile ölçülen değerler ise bu verileri ortak para birimi cinsine dönüştürmenin çeşitli sakıncaları olduğunu düşünen araştırmacılar da vardir. Kasa (1992), Chung ve Liu (1994), Alexander ve Thillainathan (1995), Alexander (2001), Click ve Plummer (2005) ve Tan (2012) yaptiklar1 çalışmalarda yalnızca sermaye piyasalarında oluşan fiyat değişimlerinin araştırmaya yansıtılabilmesi için yerel para cinsinden veriler kullanmışlardır.

Campbell vd. (2010) araştırmalarında olay analizi yapmaya yarayan istatistiksel testlerin performansını ortaya koymaya çalışmıştır. Çalışmada Amerika dişında birçok ülkeye ait 1988-2006 dönemini kapsayan günlük hisse senedi verileri kullanılmıştır. Çalışmada değişkenlere ilişkin hem yerel para birimi cinsinden veriler hem de dolar bazlı veriler kullanılmıştır. Her iki durumda da sonuçların önemli ölçüde benzerlik gösterdiği görülmüştür.

$\mathrm{Bu}$ araştırmada para piyasaları ile ilgili alınan kararların ve uygulamaların endeksler üzerindeki dolaylı etkisinden kaçınmak için ortak para birimi yerine yerel para birimi cinsinden veriler kullanılmıştır.

Çalışma kapsamında 6 ülke borsa endekslerine ait 15 yıllık süreçte toplam 22.623 günlük borsa kapanış verisiyle 50 derecelendirme not duyurusu analiz edilmiştir. Analizde anormal getiri (AR) hesaplanmasında https://eventstudytools.com adresinden yardım alınmıştır. Analizde kullanılan borsa günlük kapanış değerleri https://www.investing.com adresinden, derecelendirme notlar1 ise http://www.tradingeconomics.com adresinden temin edilmiştir. Analizde günlük borsa endeks kapanış değerlerinin kullanılmasının nedeni olay çalışması yönteminin etkin işleyişinin aylık verilerin kullanımına göre günlük verilerle daha mümkün olmasıdır (Brown \& Warner, 1985: 29). 
KDK'lar kısa süreler içerisinde farklı görünüm ve not bildiriminde bulunabilmektedirler. $\mathrm{Bu}$ durum anormal getirilerde sapmalara yol açabilmektedir. İncelenen ülkeler için KDK'ların kısa sürede benzer yönlü not açıklamaları yaptığı tespit edilmiştir. Anormal getirilerde sapmaların önlenebilmesi için analizde her üç derecelendirme kuruluşunun derecelendirme duyuruları arasında en az beş ay süre olmasına dikkat edilmiştir. Bu sayede analizde meydana gelebilecek sapmaların önlenmesi hedeflenmiştir. Derecelendirme duyuruları incelenirken analize dahil edilecek olayların belirli bir filtreden geçirilerek seçilmesi ilk kez Pinches ve Singleton (1978) tarafından gerçekleştirildiği düşünülmektedir.

Derecelendirme şirketleri, 2004-2019 y1lları arasında Türkiye için 63, Brezilya için 70 , Rusya için 56 , Hindistan için 21 , Çin için 29 , G.Afrika için ise 42 adet görünüm ve not bildiriminde bulunmuşlardır (tradingeconomics,2019). Not açıklamaları arasında en az beş aylık bir zaman aralığının konması sonucu çalışmada 2008 öncesi periyotta zaman aralığı dahilinde not düşüşüne ait herhangi bir duyuru tespit edilememiştir.

Görünüm bildirimlerinin dışarıda tutularak sadece ülke not değişimlerinin analize dahil edildiği çalışmada analizi gerçekleştirilen olaylara Tablo 3'de yer verilmiştir.

Tablo 3. Analize Konu Olan Derecelendirme Olayları ve Tarihleri

\begin{tabular}{|c|c|}
\hline Olay Tarihi & Olay \\
\hline 21.01.2004 & Fitch tarafından Hindistan için yayınlanan not artışı. $(\mathrm{BB} \rightarrow \mathrm{BB}+)$ \\
\hline 27.01.2004 & S\&P tarafindan Rusya için yayınlanan not artışı. $(\mathrm{BB} \rightarrow \mathrm{BB}+)$ \\
\hline 09.02.2004 & Fitch tarafindan Türkiye için yayınlanan not artışı. $(\mathrm{B} \rightarrow \mathrm{B}+)$ \\
\hline 17.02.2004 & S\&P tarafindan Çin için yayınlanan not artışı. (BBB $\rightarrow$ BBB+) \\
\hline 17.08.2004 & S\&P tarafindan Türkiye için yayınlanan not artışı. (B+ $\rightarrow$ BB-) \\
\hline 09.09 .2004 & Moody's tarafindan Brezilya için yayınlanan not artışı. (B1 $\rightarrow$ B2) \\
\hline 18.11.2004 & Fitch tarafından Rusya için yayınlanan not artışı. (BB+ $\rightarrow$ BBB-) \\
\hline 11.01.2005 & Moody's tarafından G.Afrika için yayınlanan not artışı. (Baa2 $\rightarrow$ Baa1) \\
\hline 02.02.2005 & $\mathrm{S} \& \mathrm{P}$ tarafindan Hindistan için yayınlanan not artışı. $(\mathrm{BB} \rightarrow \mathrm{BB}+)$ \\
\hline 19.07.2005 & S\&P tarafindan Çin için yayınlanan not artışı. (BBB+ $\rightarrow$ A-) \\
\hline 01.08.2005 & S\&P tarafindan G.Afrika için yayınlanan not artışı. (BBB $\rightarrow \mathrm{BBB}+)$ \\
\hline 03.08.2005 & Fitch tarafindan Rusya için yayınlanan not artışı. (BBB- $\rightarrow$ BBB) \\
\hline 12.10.2005 & Moody's tarafindan Brezilya için yayınlanan not artışı. (B1 $\rightarrow$ Ba3) \\
\hline 14.12.2005 & Moody's tarafından Türkiye için yayınlanan not artışı. (B1 $\rightarrow$ Ba3) \\
\hline 28.06.2006 & Fitch tarafından Brezilya için yayınlanan not artışı. (BB- $\rightarrow$ BB) \\
\hline 25.07 .2006 & Fitch tarafından Rusya için yayınlanan not artışı. (BBB $\rightarrow \mathrm{BBB}+)$ \\
\hline 27.07.2006 & S\&P tarafindan Çin için yayınlanan not artışı. (A- $\rightarrow$ A) \\
\hline 01.08.2006 & Fitch tarafindan Hindistan için yayınlanan not artışı. (BB $+\rightarrow$ BBB-) \\
\hline $\mathbf{1 0 . 0 5 . 2 0 0 7}$ & Fitch tarafindan Brezilya için yayınlanan not artışı. $(\mathrm{BB} \rightarrow \mathrm{BB}+)$ \\
\hline 26.07.2007 & Moody's tarafindan Çin için yayınlanan not artışı. (A2 $\rightarrow$ A1) \\
\hline 30.04.2008 & S\&P tarafindan Brezilya için yayınlanan not artışı. (BB+ $\rightarrow$ BBB-) \\
\hline 16.07 .2008 & Moody’s tarafindan Rusya için yayınlanan not artışı. (Baa2 $\rightarrow$ Baa1) \\
\hline 31.07.2008 & S\&P tarafindan Çin için yayınlanan not artışı. $(\mathrm{A} \rightarrow \mathrm{A}+)$ \\
\hline 08.12.2008 & S\&P tarafindan Rusya için yayınlanan not düşüşü. (BBB+ $\rightarrow \mathrm{BBB})$ \\
\hline 16.07.2009 & Moody’s tarafindan G.Afrika için yayınlanan not artışı. (Baa1 $\rightarrow$ A3) \\
\hline 22.09.2009 & Moody's tarafindan Brezilya için yayınlanan not artışı. (Ba1 $\rightarrow$ Baa3) \\
\hline 03.12.2009 & Fitch tarafindan Türkiye için yayınlanan not artışı. (BB- $\rightarrow B B+)$ \\
\hline 11.11.2010 & Moody’s tarafindan Çin için yayınlanan not artışı. (A1 $\rightarrow$ Aa3) \\
\hline 04.04.2011 & Fitch tarafindan Brezilya için yayınlanan not artışı. (BBB- $\rightarrow$ BBB) \\
\hline
\end{tabular}


Musa Ovalı \& Turan Kocablyık \& Umut Burak Geyikçi / Kredi Derecelendirmenin Borsa Endeksleri Üzerindeki Etkileri: T-BRICS Ülkeleri Üzerine Bir Araştırma

\begin{tabular}{|c|c|}
\hline 17.11.2011 & S\&P tarafindan Brezilya için yayınlanan not artışı. (BBB- $\rightarrow$ BBB) \\
\hline 20.06.2012 & Moody's tarafından Türkiye için yayınlanan not artışı. (Ba2 $\rightarrow$ Ba1) \\
\hline 27.09.2012 & Moody’s tarafindan G.Afrika için yayınlanan not düşüşü. (A3 $\rightarrow$ Baa1) \\
\hline 27.03.2013 & $\mathrm{S} \& \mathrm{P}$ tarafindan Türkiye için yayınlanan not artışı. $(\mathrm{BB} \rightarrow \mathrm{BB}+)$ \\
\hline 24.03.2014 & S\&P tarafindan Brezilya için yayınlanan not düşüşü. (BBB $\rightarrow$ BBB-) \\
\hline 25.04.2014 & S\&P tarafindan Rusya için yayınlanan not düşüşü. (BBB $\rightarrow$ BBB-) \\
\hline 13.06.2014 & S\&P tarafindan G.Afrika için yayınlanan not düşüşü. (BBB $\rightarrow B B B)$ \\
\hline 17.10.2014 & Moody’s tarafindan Rusya için yayınlanan not düşüşü. (Baa1 $\rightarrow$ Baa2) \\
\hline 11.08.2015 & Moody's tarafindan Brezilya için yayınlanan not düşüşü. (Baa2 $\rightarrow$ Baa3) \\
\hline $\mathbf{0 4 . 1 2 . 2 0 1 5}$ & Fitch tarafindan G.Afrika için yayınlanan not düşüşü. (BBB $\rightarrow$ BBB-) \\
\hline 17.02.2016 & S\&P tarafindan Brezilya için yayınlanan not düşüşü. (BB+ $\rightarrow \mathrm{BB})$ \\
\hline 20.07.2016 & S\&P tarafindan Türkiye için yayınlanan not düşüşü. $(\mathrm{BB}+\rightarrow \mathrm{BB})$ \\
\hline 27.01.2017 & Fitch tarafından Türkiye için yayınlanan not düşüşü. (BBB- $\rightarrow \mathrm{BB}+)$ \\
\hline 03.04.2017 & S\&P tarafindan G.Afrika için yayınlanan not düşüşü. (BBB- $\rightarrow \mathrm{BB}+$ ) \\
\hline 24.05.2017 & Moody’s tarafindan Çin için yayınlanan not düşüşü. (Aa3 $\rightarrow$ A1) \\
\hline 16.11.2017 & Moody's tarafından Hindistan için yayınlanan not artışı. (Baa3 $\rightarrow$ Baa2) \\
\hline 24.11.2017 & S\&P tarafindan G.Afrika için yayınlanan not düşüşü. (BB+ $\rightarrow \mathrm{BB})$ \\
\hline 11.01.2018 & S\&P tarafindan Brezilya için yayınlanan not düşüşü. (BB $\rightarrow$ BB-) \\
\hline 23.02.2018 & S\&P tarafindan Rusya için yayınlanan not artışı. (BB+ $\rightarrow$ BBB-) \\
\hline 07.03.2018 & Moody’s tarafindan Türkiye için yayınlanan not düşüşü. (Ba1 $\rightarrow$ Ba2) \\
\hline 08.02.2019 & Moody's tarafından Rusya için yayınlanan not artışı. (Ba1 $\rightarrow$ Baa3) \\
\hline
\end{tabular}

Kaynak: (www.tradingeconomics.com adresinden derlenmiştir.)

$\mathrm{Bu}$ araştırmanın amacı derecelendirme kuruluşlarının yayınladıkları not değişim duyurularının borsa endeksleri üzerinde etkisinin olup olmadığının ortaya konmasıdır. Bu amaçla T-BRICS ülkelerine ait borsa endekslerinin not değişim duyurularından etkilenip etkilenmediği yapılacak analizlerle tespit edilmeye çalışılacaktır. Buradan hareketle, temel araştırma hipotezleri;

$H_{0}$ : Kredi derecelendirme not duyuruları, gerçekleşen tarih etrafında TBRICS hisse senedi piyasalarında meydana gelen anormal getirilerde bir farklılığa neden olmaz. $H_{0}: A R_{i}=0$

$H_{I}$ : Kredi derecelendirme not duyuruları, gerçekleşen tarih etrafinda TBRICS hisse senedi piyasalarında meydana gelen anormal getirilerde bir farklılığa neden olur. $H_{l}=A R_{i t} \neq 0$

olarak belirlenmiştir.

\subsection{Olay çalışması yöntemi}

Bir dönemde meydana gelen olay karşısında piyasanın göstermiş olduğu anormal tepkiyi ölçmek için kullanılan yönteme olay çalışması yöntemi denmektedir (Sakarya, 2011: 153). Bu yöntemde anormal getirilerin hesaplanmasında çeşitli modeller kullanılmaktadır. Dyckmani, Philbrick ve Stephan (1984) çalışmalarında anormal getirinin tespiti için "Düzeltilmiş ortalama getiri modeli, Piyasaya göre düzeltilmiş getiri modeli ve Piyasa modeli', olmak üzere üç farklı model kullanmışlardır. Binder (1998) ise olay metodolojisine kapsamlı yer verdiği çalışmasında beş metodu ele almıştır. Bunlar; "Ortalama ayarlı, Piyasa ayarlı, Piyasa modeli, Tek faktörlü normal getiri tahmini ve Çok faktörlü normal getiri tahmini”. Bu modellerin sayısız kullanıldığ araştırmalarda piyasa modeline yakın sonuçlar verdiği tespit edilmiştir. Literatürde anormal getirinin tespitinde kullanılan modeller arasında piyasa modelinin en çok kabul gören model olduğunu ifade eden çalışmalar mevcuttur 
(Binder, 1998; Sorokina, vd., 2013). Analizde anormal getirilerin tespitinde piyasa modeli kullanılmıştır.

Bir olayın etkisini ölçmek için anormal getirinin ölçüm şekli belirlenmelidir. Bunu hesaplarken, normal getiri olarak alınacak bir piyasa getirisi belirlenmelidir. Piyasa getirisi, olağandışı durumun bulunmadığı standart endeks getirisini ifade etmektedir. Anormal getiri mevcut piyasada gerçekleşen getiri ile piyasa getirisi arasındaki fark olarak bulunmaktadır. Çalışmada gerçekleşen getiri olarak ülke piyasalarına ait günlük endeks getirileri, piyasa getirisi olarak ise Moshirian (2009) ve Klimavičienė (2011) çalışmalarında kullandığı MSCI EM Index günlük endeks getirileri kullanılmıştır.

Analizde anormal getirinin(AR) hesaplanırken kullanılan adımlar şunlardır (Mackinlay, 1997; Koçyiğit ve Kılıç, 2008; Neuhierl, vd., 2013;);

Denklem (1)'de yer alan;

$$
\mathrm{R}_{\mathrm{i}, \mathrm{t}}: \alpha i+\beta i R m t+\varepsilon i t
$$

$\mathrm{R}_{i t} \mathrm{i}$ hisse senedi piyasasının t gününde meydana gelen fiili getirisini, $\mathrm{R} m t$ : $\mathrm{t}$ gününe ait piyasa getirisini (MSCI EM Endeksinin getirisi), $\alpha i$ : Modelin sabit katsayısını,

$\beta i$ : Hisse senedi piyasasına ait sistematik riski(eğimi), cit: Hata terimini ifade etmektedir.

Piyasaya ilişkin günlük getiri şöyle hesaplanmaktadır;

$$
\mathrm{R}_{m t} \frac{I t-I(t-1)}{I(t-1)}
$$

Denklem (2)'de yer alan;

$I_{t}$ : MSCI Endeksinin $t$ günündeki kapanış değerini,

$I_{(t-1)}$ : MSCI Endeksinin t-1 gününde gerçekleşen kapanış değerini göstermektedir.

Denklem 3'te yer alan;

$$
\mathrm{AR}_{\mathrm{it}:} \mathrm{R}_{\mathrm{it}}-(\alpha i+\beta i R m t)
$$

$\mathrm{AR}_{i, t}$ : i hisse senedi piyasasının $\mathrm{t}$ anındaki anormal getiri oranını, $\mathrm{R}_{i t}$, i hisse senedi piyasasının $\mathrm{t}$ anında gerçekleşen getiri oranını, $\mathrm{R}_{m t}: \mathrm{t}$ gününe ait piyasa getirisini (MSCI EM Endeksinin getirisi), $\alpha i$ : Modelin sabit katsayısını,

$\beta i$ : Hisse senedi piyasasına ait sistematik riski(eğimi), ifade etmektedir.

Bir olayin olay penceresinde belirlenen süre boyunca toplam etkisinin ölçülmesi için anormal getirileri bir arada toplayarak kümülatif anormal getiri(CAR) elde edilebilir. İlgili değerin hesaplanması için kullanılan formül şu şekilde ifade edilmektedir;

\section{$\mathrm{CAR}_{\mathrm{i}}: \sum$ ARit}

İlgili hesaplamalar sonucunda, elde edilen kümülatif anormal getirilerin 0'dan farklı olması, gerçekleşen olayın borsa endeksini etkileyerek ilgili endekste anormal bir getiri imkanı sunduğu anlamına gelmektedir (Sakarya,2011:155).

Bir çalışmada aynı olay tipinde birden fazla olay için bir analiz yapıldığında olay gününden önce ya da sonra belirli bir zaman aralığını kapsayan 
birden fazla olaya ait anormal getirilerin ortalamasına ortalama anormal getiri(AAR) denmektedir. AAR, formülle şu şekilde ifade edilmektedir;

$$
\text { AAR: } \frac{1}{\mathrm{n}} \sum_{i=1}^{n} \mathrm{AR} i, t
$$

Bireysel olay türlerinin (Örn: satın alma ve birleşme) çoklu gözlemlerini içeren bir olay çalışmasında, aynı olayların ortalama değerlerini temsil eden kümülatif ortalama anormal getiri (CAAR) hesaplanabilmektedir. Denklem 4'te CAAR'nın hesaplanması için temel alınan formül gösterilmektedir. $\mathrm{Bu}$ denklemde yer alan $\mathrm{AR}_{\mathrm{it}} \mathrm{i}$ hisse senedi piyasasının $\mathrm{t}$ zamanındaki anormal getirisini, $C A R\left(t_{1}, t_{2}\right)$ ise $t 1$ ve $t 2$ zamanında kümülatif ortalama anormal getiriyi ifade etmektedir. Kümülatif ortalama anormal getiri hesaplanırken şu formül kullanılmaktadır;

$$
\text { CAAR: } \frac{1}{\mathrm{n}} \sum_{i=1}^{n} \operatorname{CAR}(t 1, t 2)
$$

Anormal getirilerin anlamlılığının test edilmesi için $t$ istatistiği kullanılmaktadır.

$$
t \mathrm{AR} i, \mathrm{t}: \frac{A R i, t}{S A R i}
$$

Denklem 7'te yer alan;

$t \mathrm{AR}_{\mathrm{i}, \mathrm{t}}$ : Anormal getirinin $\mathrm{t}$ istatistiki değerini,

$\mathrm{AR}_{\mathrm{i}, \mathrm{t}}$ : Günlük anormal getiriyi,

$S_{A R i}$ : Tahmin penceresinde anormal getirilerin standart sapmasin1

ifade etmektedir.

$$
t C A R i=\frac{C A R i}{S C A R}
$$

Denklem 8'de yer alan;

$\mathrm{S}_{C A R:} \mathrm{CAR} i$ değerine ait standart sapma. Varyansın karekökü alınarak bulunmuştur. Varyans ise şu formülle hesaplanmıştır;

$$
\mathrm{S}^{2}{ }_{C A R}=L S^{2}\left(A R_{t}\right)
$$

Denklem 9'da yer alan;

$L$; Olay penceresine dahil edilen gün sayısını ifade etmektedir.

Analizde normal getirilerin tespitinde kullanılacak yöntem belirlendikten sonra sıra, tahmin ve olay penceresinin belirlenmesine gelmektedir. Şekil 1'de araştırmada kullanılan olay çalışması zaman çizelgesine yer verilmiştir.

Şekil 1. Araştırmaya Ait Olay Çalışması Zaman Çizelgesi

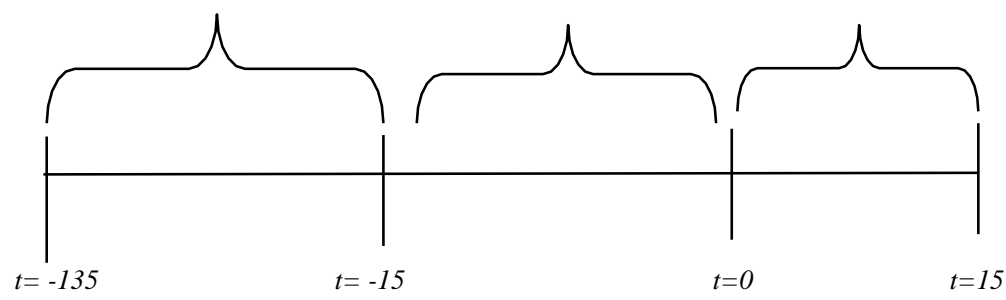

Araştırmada not duyuru tarihi olay tarihi (t) olarak kabul edilmiştir. Olay penceresi, Brown ve Warner (1985), Correa vd. (2014) ve Korkmaz, Yaman ve Metin (2017) çalışmalarından yararlanılarak dört aralıkta belirlenmiştir; $(-15 ; 15)$, 
$(-10 ;+10),(-5 ;+5)$ ve $(-1 ;+1)$. Olay penceresinin uzun süreyi kapsaması diğer haberlerden dolayı borsanın etkilenebileceği ve olayın anlamlılığı konusunda yanıltıcı bilgiler verebileceği varsayılmaktadır. Olay penceresinin kısa bir süreyi kapsaması olayın önemli etkilerini açık şekilde yansıtabilmektedir (Sakarya,2011:152).

\section{BULGULAR}

$\mathrm{Bu}$ çalışmada 2004-2019 yılları arasında gerçekleşen derecelendirme duyurularının T-BRICS ülkelerine ait seçilen hisse senedi piyasaları üzerindeki etkileri incelenmiştir. Çalışmanın bu bölümünde analize ait bulgular sunulmuştur. Olay penceresinde, gerçekleşen derecelendirme not duyuruları dışında piyasa getirilerini etkileyen olay ve gelişmeler hakkındaki bilgiler https://sputniknews.com, https://www.nytimes.com ve https://www.theguardian.com adreslerinden alınmıştır. Kirlenmiş olay olarak nitelendirilen olaylar; Türkiye için 09.02.2004 (not artış) ve 20.07.2016 (not düşüş) tarihli olaylar, Hindistan için 21.01.2004 ve 02.02.2005 tarihli not artış olayları, Rusya için 16.07.2008 tarihli not artış olayı ve Çin için 11.11.2010 tarihli not artış olayı.

Tablo 4'te 2008 öncesi dönemde not artışına ait istatistiki olarak anlamlı anormal getiri oranları sunulmuştur

Tablo 4. 2008 Öncesi Not Artışına Ait AR Tablosu $(-15 ;+15)$

\begin{tabular}{|c|c|c|c|c|c|c|c|c|c|c|c|c|c|c|c|c|c|c|}
\hline Ülke & & irkiy & & & & & & & & & ndis & & & & & & & \\
\hline Olay & 09 & 17 & 13 & 09 & 12 & 28 & 10 & 18 & 03 & 21 & 02 & 01. & 1 & 19 & 27 & 26 & 1 & 01 \\
\hline Tarihi & .0 & .0 & .1 & .0 & .1 & .0 & .0 & .1 & .0 & .0 & .0 & 08. & 7. & .0 & .0 & .0 & 1. & .0 \\
\hline & 2 & 8. & 2. & 9. & 0. & 6. & 5. & 1. & 8. & 1. & 2. & 20 & 0 & 7. & 7. & 7. & 0 & 8. \\
\hline & 20 & 20 & 20 & 20 & 20 & 20 & 20 & 20 & 20 & 20 & 20 & 06 & 2. & 20 & 20 & 20 & 1. & 20 \\
\hline & 04 & 04 & 05 & 04 & 05 & 06 & 07 & 04 & 05 & 04 & 05 & & 2 & 05 & 06 & 07 & 2 & 05 \\
\hline $\begin{array}{l}\text { Olay } \\
\text { Pence } \\
\text { Pesi }\end{array}$ & & & & & & & & & & & & & $\begin{array}{l}0 \\
0 \\
4\end{array}$ & & & & $\begin{array}{l}0 \\
0 \\
5\end{array}$ & \\
\hline AR(- & & & & & & & & & & & - & & & & & - & & \\
\hline 15) & & & & & & & & & & & 0 & & & & & 0 , & & \\
\hline & & & & & & & & & & & $\begin{array}{l}01 \\
0 *\end{array}$ & & & & & $\begin{array}{l}05 \\
6 *\end{array}$ & & \\
\hline & & & & & & & & & & & $*$ & & & & & $*$ & & \\
\hline AR(- & & & & & & & & & & & 0 & & & & & & & \\
\hline 14) & & & & & & & & & & & $\begin{array}{l}0, \\
01\end{array}$ & & & & & & & \\
\hline & & & & & & & & & & & $8^{*}$ & & & & & & & \\
\hline & & & & & & & & & & & $*$ & & & & & & & \\
\hline $\begin{array}{l}\text { AR(- } \\
\text { 13) }\end{array}$ & & & & & & $\begin{array}{l}0, \\
03\end{array}$ & & & & & 0 & & & & & & & \\
\hline & & & & & & $5^{*}$ & & & & & 02 & & & & & & & \\
\hline & & & & & & & & & & & $* *$ & & & & & & & \\
\hline AR(- & & & & & & & & & & & & & - & & & & & \\
\hline 12) & - & & & & 0 & & & & & & 0 & & 0 , & & & & & \\
\hline & 0 & & & & 02 & & & & & & 01 & & 0 & & & & & \\
\hline & 03 & & & & $8^{*}$ & & & & & & $6^{*}$ & & $\begin{array}{l}2 \\
4\end{array}$ & & & & & \\
\hline & $6^{*}$ & & & & & & & & & & & & * & & & & & \\
\hline & & & & & & & & & & & & & * & & & & & \\
\hline AR(- & & & 0 , & & & - & & & & & 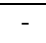 & & 0 , & & & & & \\
\hline 11) & 0 & & 02 & & & 0 & & & & & 0 & & 0 & & & & & \\
\hline
\end{tabular}


Musa Ovalı \& Turan Kocablyık \& Umut Burak Geyikçi / Kredi Derecelendirmenin Borsa Endeksleri Üzerindeki Etkileri: T-BRICS Ülkeleri Üzerine Bir Arastırma

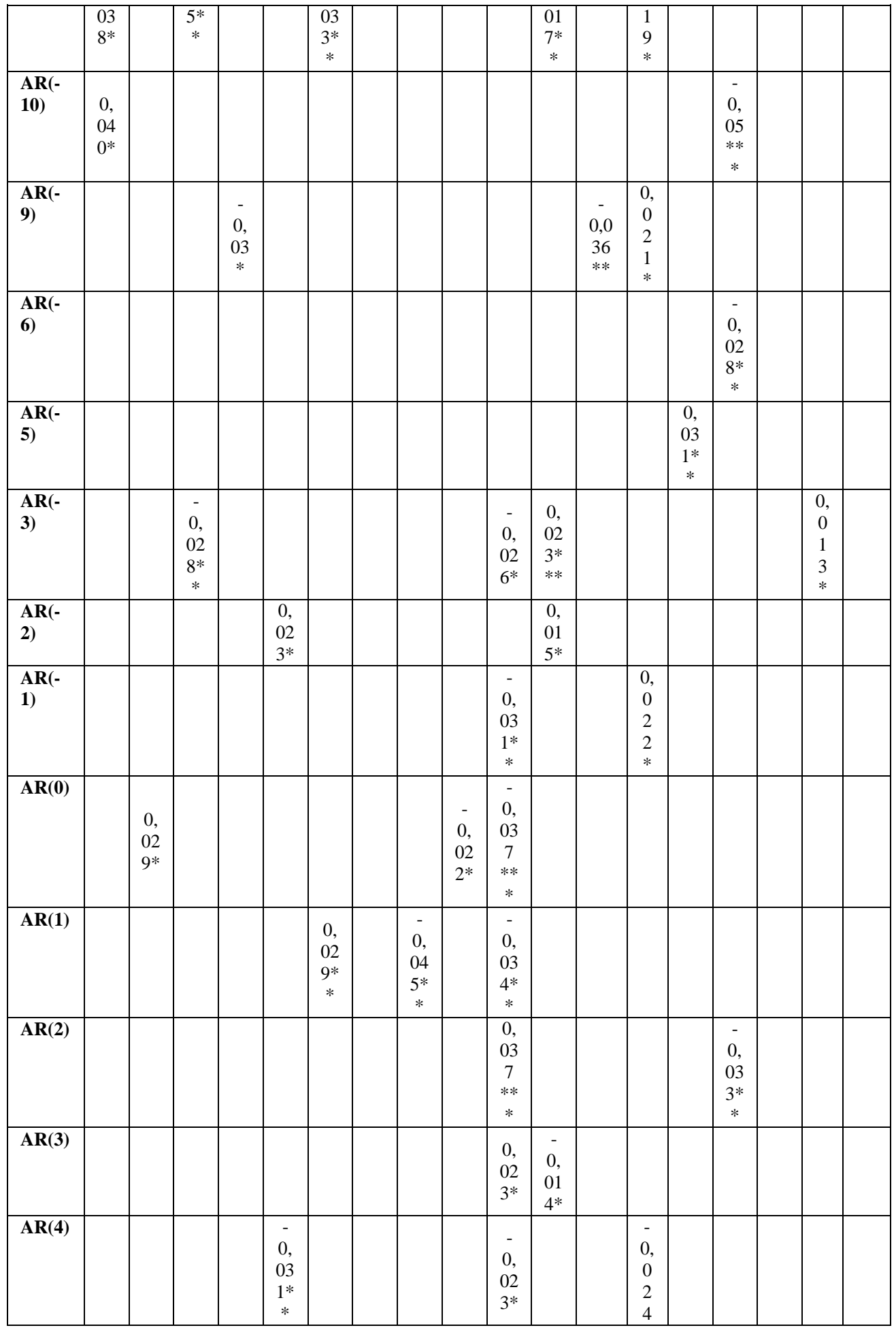




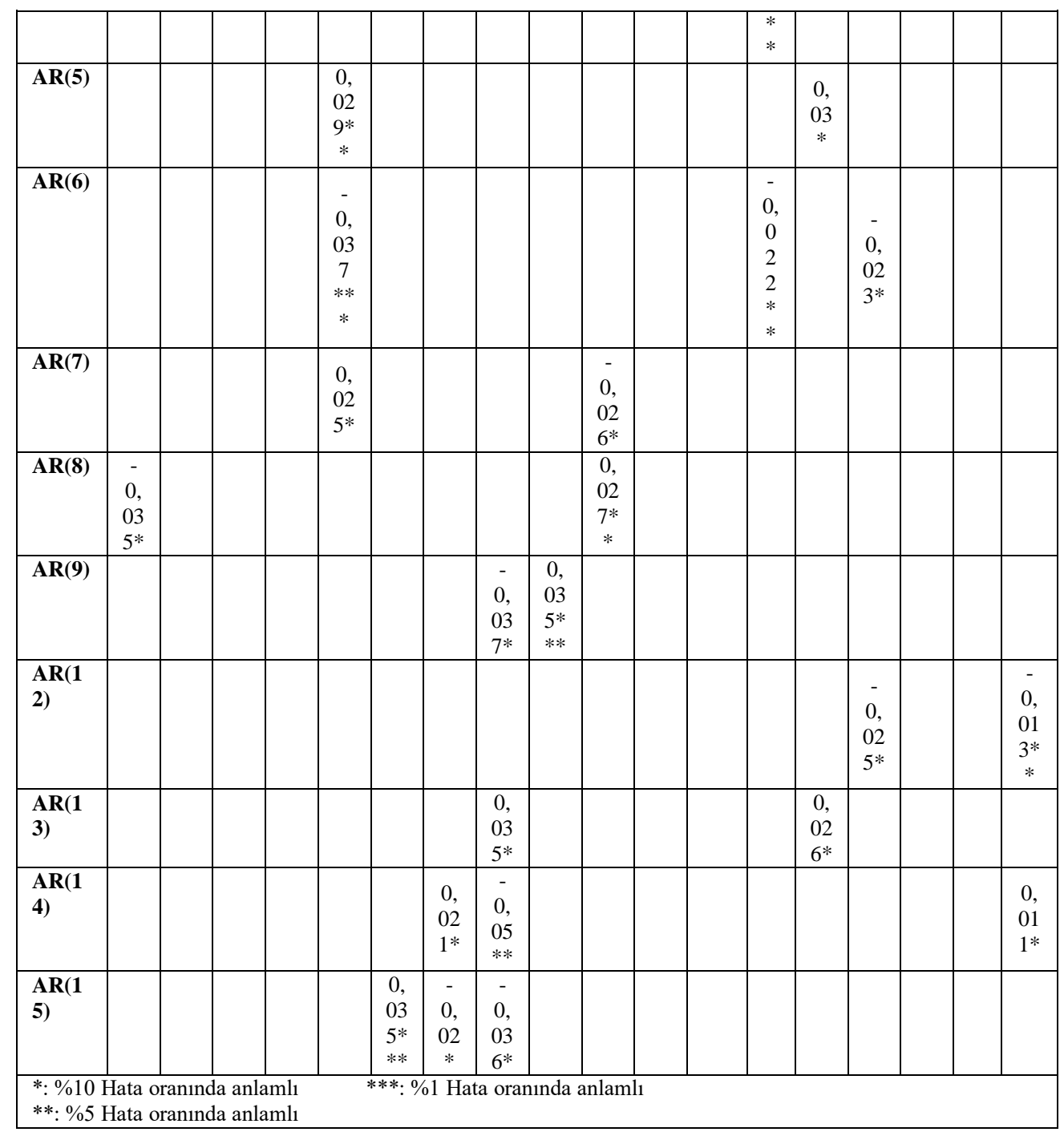

Tablo 4 incelendiğinde, 2008 öncesi dönemde, Türkiye için üç, Brezilya için dört, Rusya için dört, Hindistan için üç, Çin için dört ve G.Afrika için iki not artışı gerçekleşmiştir.

Tabloya 4'e göre, Türkiye'de 09.02.2004 tarihli olayda (t-12), (t-11), (t10) günlerinde sırasıyla; \%-3,62, \%-3,87 ve \%4,08 oranlı anormal getiriler tespit edilmiştir. Anormal getirilerin görüldüğü günlerde Merkez Bankası tarafından dış ticaret açığının 2003 Ocak-Kasım döneminde geçen yıla oranla \%63,3 arttığ açıklaması yapılmıştır. Bu açıklamanın, olumlu bir olay öncesinde gerçekleşen negatif anormal getirilere neden olduğu düşünülmektedir. (t-10) gününde gerçekleşen $\% 4,7$ oranındaki getirinin de olaydan bağımsız bir fiyatlama olabileceği ihtimalinden 31.01.2004 tarihi incelenmiş ve bu tarihte Türk Lirasından altı sıfır atılması kararı resmi gazetede yayınlandığı tespit edilmiş, bu 
durum piyasalarda olumlu algılanmıştır. $\mathrm{Bu}$ gelişmenin, ilgili anormal getirinin kaynağı olabileceği şeklinde yorumlanmıştır. Olay sonrasında ise sadece $(\mathrm{t}+8)$. günde \%-3,56 oranında anlamlı anormal getiri tespit edilmiştir.

Türkiye için 17.08.2004 tarihli olayda, olay gününde \%10 hata payıyla $\% 2,95$ oranında anormal getiri tespit edilmiştir. 13.12.2005 tarihli olayda ise (t11) ve (t-3) gününde anormal getiri tespit edilmiştir. Tespit edilen bu getiriler sirasiyla $\% 2,51$ ve $\%-2,88$ oranındadir.

Brezilya için 09.09.2004 tarihli olayda anormal getiri sadece (t-9). günde $\% 10$ hata payıyla \%3 oranında gerçekleşmiştir. 12.10.2005 tarihli diğer olayda (t12) ve $(\mathrm{t}-2)$ günlerinde anormal getiri tespit edilmiş, olay sonrasında ise $(\mathrm{t}+4)$, $(\mathrm{t}+5),(\mathrm{t}+6),(\mathrm{t}+7)$ günlerinde anlamlı anormal getiriler bulgulanmıştır. 28.06.2006 tarihli olayda $(\mathrm{t}-13),(\mathrm{t}-11),(\mathrm{t}+1)$ ve $(\mathrm{t}+15)$ günlerinde anlamlı anormal getiri tespit edilmiştir. Son olarak 10.05.2007 tarihli not artış olayında Brezilya'da $(t+14)$. ve $(t+15)$. günlerde anormal getiriler tespit edilmiştir. 2008 öncesi not artışlarında Brezilya'da istatistiki olarak anlamlı 13 adet anormal getirinin varlığı tespit edilmiştir.

Rusya'da olay öncesinde anormal getiriye rastlanılmamıştır. Bu nedenle Rusya piyasasının ilgili olaylarda etkin özellik gösterdiği söylenebilir. 18.11.2004 tarihli olayda $(\mathrm{t}+1),(\mathrm{t}+9),(\mathrm{t}+13),(\mathrm{t}+14)$ ve $(\mathrm{t}+15)$ günlerinde anormal getiriler tespit edilmiştir. 03.08.2005 tarihli olayda ise sadece $(\mathrm{t} 0)$ ve $(\mathrm{t}+9)$ günlerinde anormal getiri tespit edilmiştir.

Tablo 4'teki tüm anormal getiriler incelendiğinde genel anlamda analize konu olan olay olumlu derecelendirme duyurusu olmasına rağmen bazı ülke piyasalarında negatif anormal getirilerin olduğu görülmektedir. Hindistan'da 21.01.2004 tarihli olayda $(\mathrm{t}-3),(\mathrm{t}-1),(\mathrm{t} 0),(\mathrm{t}+1),(\mathrm{t}+2),(\mathrm{t}+3),(\mathrm{t}+4),(\mathrm{t}+7)$, ve $(\mathrm{t}+8)$ günlerinde istatistiki olarak anlamlı 9 adet anormal getiri tespit edilmiştir. Olumlu bir not açıklaması olmasına karşın (t0) gününde istatistiki olarak 1\% hata payıyla $\%$-3,7'lik bir negatif anormal getiri tespit edilmiştir. İncelemede Hindistan' 1 n o tarihlerde iç karışıklıklar ve terör sorunları yaşadığı tespit edilmiştir. Bu durumun getiriler üzerinde etkili olabileceği düşünülmektedir. 02.02.2005 tarihli not artırımında (t-15), (t-14), (t-13), (t-12), (t-11) gününe kadarki 5 günlük süreçte ve (t-3), (t-2) günlerinde anlamlı anormal getiri tespit edilmiştir. $\mathrm{Bu}$ anormal getirilere piyasalardan bağımsı başka bir olayın etki edebileceği düşünülmektedir; doğal afet. Yapılan incelemede Ocak 2005 tarihinde büyük bir kasırganın Hindistan'1 vurduğu, 12.000'den fazla can kaybına yol açtığı, ülkenin hem ekonomik hem de sosyal hayatını etkilediği tespit edilmiştir.

Hindistan'da 01.08.2006 tarihli olayda ise sadece (t-9).günde \%5 hata payıyla anlamlı -\%3,6 oranında anormal getiri tespit edilmiştir.

Çin'e ait 17.02.2004 tarihli olayda (t-12), (t-11), (t-9) ve (t-1) günlerinde anormal getiri tespit edilmiştir. Olay gününden sonra $(t+4)$ ve $(t+6)$ günlerinde her ikisi de $\% 5$ hata payıla negatif anormal getirilerin tespiti piyasada beklentinin sona erdiği şeklinde yorumlanabilir. 27.07.2006 tarihli olayda ise (t-10), (t-6), $(t+2),(t+6)$ ve $(t+9)$ günlerinde negatif anormal getiriler tespit edilmiştir. Olay tarihinden önce anormal getirilerin varlığı, piyasada bilgi sızıntısı olabileceği 
şeklinde yorumlanabilir. Bu durum Çin hisse senedi piyasasının yarı etkin formda etkin olmadığ 1 şeklinde yorumlanabilir.

G.Afrika'da ise 11.01.2005 tarihli olayda sadece (t-3) gününde olayla aynı yönde $\% 10$ hata oranında $\% 1,3$ pozitif anormal getiri tespit edilmiştir. G.Afrika için bir diğer olay olan 01.08.2005 tarihinde ise $(t+12)$ ve $(t+14)$ günlerinde anlamlı anormal getiriler tespit edilmiştir.

Tablo 4'te yer alan tüm anormal getiriler incelendiğinde $(-5 ;+5)$ aralığında 24 adet anlamlı anormal getiri tespit edilmiş, bunlardan 12 tanesi negatif yönde gerçekleşmiştir. 15 anormal getiri, olay gününde ve devam eden 5 günlük süreçte meydana gelmiştir. $(-1 ;+1)$ olay penceresinde ise 8 anormal getiri tespit edilmiş olup bunlardan dördü negatif kalan dördü ise pozitif yönlü gerçekleşmiştir. 2008 öncesi gerçekleşen ülke derece not artışları olay gününe yakın aralıklarda anormal getiriye neden olduğu tespit edilmiştir.

Tablo 5'te 2008 sonrası dönemde not artışına ait istatistiki olarak anlamlı anormal getiri oranları sunulmuştur.

Tablo 5. 2008 Sonrası Not Artışına Ait AR Tablosu (-15;+15)

\begin{tabular}{|c|c|c|c|c|c|c|c|c|c|c|c|}
\hline Ülke & \multicolumn{2}{|c|}{ Türkiye } & \multicolumn{2}{|c|}{ Brezilya } & \multicolumn{3}{|c|}{ Rusya } & Hindistan & \multicolumn{2}{|c|}{ Çin } & G. Afrika \\
\hline $\begin{array}{r}\text { Olay } \\
\text { Tarihi } \\
\text { Olay } \\
\text { Penceresi }\end{array}$ & $\mid \begin{array}{c}03.12 \\
\cdot \\
2009\end{array}$ & $\begin{array}{c}20.06 \\
\dot{\cdot} \\
2012\end{array}$ & $\begin{array}{c}30.04 . \\
2008\end{array}$ & $\mid \begin{array}{c}04.04 \\
\cdot \\
2011\end{array}$ & $\begin{array}{c}16.07 \\
2008\end{array}$ & $\begin{array}{c}23.02 \\
\dot{ } \\
2018\end{array}$ & $\begin{array}{c}08.02 . \\
2019\end{array}$ & $\begin{array}{c}16.11 . \\
2017\end{array}$ & $\begin{array}{c}31.0 \\
7 . \\
2008\end{array}$ & $\begin{array}{c}11.11 \\
\dot{2} \\
2010\end{array}$ & $\begin{array}{c}16.07 . \\
2009\end{array}$ \\
\hline $\mathbf{A R}(-13)$ & & & & $\begin{array}{c}0, \overline{0} \\
0 \\
*\end{array}$ & & & & & & & \\
\hline $\mathbf{A R}(-10)$ & $\begin{array}{c}0,032 \\
* *\end{array}$ & & & & & & & & & & \\
\hline $\mathbf{A R}(-9)$ & & & & & & & & & $\begin{array}{c}0,04 \\
57 *\end{array}$ & & \\
\hline $\mathbf{A R}(-7)$ & & & & & & & & $-0,012 * * *$ & & & \\
\hline $\mathbf{A R}(-3)$ & & & & & $0,028 *$ & & & & & & $0,021^{*}$ \\
\hline $\mathbf{A R}(-2)$ & & & & & $0,026^{*}$ & & & & & & \\
\hline $\mathbf{A R}(-1)$ & \begin{tabular}{|c|}
0,031 \\
$5 * * *$
\end{tabular} & & & & & $\begin{array}{c}0,015 \\
*\end{array}$ & & & & & \\
\hline $\mathbf{A R}(\mathbf{0})$ & \begin{tabular}{|c}
0,032 \\
$6 * *$ \\
\end{tabular} & & $\begin{array}{c}0,053^{* * *} \\
*\end{array}$ & & & & & & & & \\
\hline $\operatorname{AR}(\mathbf{1})$ & & $\begin{array}{c}0,028 \\
* * *\end{array}$ & & & & & & & & $\begin{array}{l}0, \overline{045} \\
* * *\end{array}$ & \\
\hline $\mathbf{A R}(2)$ & & & & $\begin{array}{c}0, \overline{0} 2 \\
*\end{array}$ & $0,032^{*}$ & & & & & & \\
\hline $\mathbf{A R}(\mathbf{3})$ & & & & & & $\begin{array}{c}0,014 \\
* *\end{array}$ & $\begin{array}{c}- \\
0,019 \\
* * *\end{array}$ & & & $\begin{array}{c}- \\
0,034 \\
* *\end{array}$ & \\
\hline $\mathbf{A R}(5)$ & & & & & & & $\begin{array}{c}0,014 \\
* * *\end{array}$ & & & & \\
\hline $\mathbf{A R}(7)$ & & & & & $\underset{* *}{0,042^{*}}$ & & & & $\begin{array}{c}- \\
0,05 \\
*\end{array}$ & & \\
\hline $\mathbf{A R}(11)$ & & & & & & & & $-0,0081 *$ & & & \\
\hline
\end{tabular}




\begin{tabular}{|l|l|l|l|l|l|l|l|l|l|l|l|}
$\mathbf{A R}(\mathbf{1 2})$ & $0,02 *$ & $0,01^{*}$ & & & & $\begin{array}{c}0,018 \\
* * *\end{array}$ & & & & & \\
\hline $\operatorname{AR}(\mathbf{1 4})$ & & & & & $\begin{array}{c}- \\
0,0312 \\
*\end{array}$ & & & & 0,06 & & \\
\hline AR(15) & & & & & & & & & \\
\hline
\end{tabular}

Tablo 5'te görüleceği üzere olumlu bir duyuru olmasına karşın negatif getiriler tespit edilmiştir. Bunun sebebi 2008 krizi sonrası gelişmekte olan ülke piyasalarının dış şoklara karşı kırılganlığının artması, krizin bulaşıcılık etkisinden dolayı farklı ülkelerde meydana gelen bir ekonomik sorunun diğer ülkeleri de etkilediği şeklinde yorumlanabilir. Anormal getiriler incelendiğinde toplamda 28 adet anormal getirinin 15 tanesinin negatif yönlü olduğu tespit edilmiştir. Negatif getirilerin 11 adedi olay gününden sonra gerçekleşmiş getirilerdir. Olay tarihinden önce 13 tane anormal getiri arasından sadece 2 tanesinin negatif anormal getiri olması, piyasada bilgi sızıntısının gerçekleştiği ihtimalini güçlendirmektedir.

Çin'de gerçekleşen 11.11.2010 tarihli olay, $(\mathrm{t}+1)$ günde $\% 1$ hata payıyla $\%-4,5$ oranında anormal getiriye yol açmıştır. İlgili tarihte Moody's tarafindan ülke derece notu A1'den yüksek yatırım yapılabilir düzey olan Aa3'e çıkarılan Çin'de böyle bir getirinin başka bir sebebi olabileceği üzerinde durulup araştırma yapılmıştır. Dönemin ABD Başkanı Obama tarafından G-20 toplantısında Çin'in ihracatı teşvik etmek amacıyla ulusal para birimini piyasa fiyatının altında tutacak piyasa müdahalelerinde bulunduğu ve uluslararası finans sistemi açısından Çin'in üzerine düşeni yeterince yapmadığ 1 üzerine açıklamalar tespit edilmiştir. Olay tarihinde ilgili anormal getirinin bu sebeplerle gerçekleştiği düşünülmektedir.

Diğer ülkeler incelendiğinde Türkiye'de 03.12.2009 tarihli olayda (t-10), $(\mathrm{t}-1)$, (t0) ve $(\mathrm{t}+12)$ günlerinde olmak üzere dört adet anormal getiri tespit edilmiştir. Bu anormal getirilerden olay öncesi meydana gelenlerin negatif yönde, olay günü ve sonrasında meydana gelenlerin ise pozitif yönde oldukları tespit edilmiştir. Türkiye'de meydana gelen 20.06.2012 tarihli olayda ise $(\mathrm{t}+1)$ ve $(\mathrm{t}+12)$ günlerinde anormal getiriler tespit edilmiştir. Diğer yandan Brezilya'da 30.04.2008 tarihli olayda (t0) gününde $\% 5,3$ anormal getiri tespit edilmiştir. Rusya'da ise 16.07.2008 tarihli olayın öncesinden başlayarak sonrasında da devam eden negatif yönlü anormal getirilerin sebebi araştırılmıştır. Rusya'nın Gürcistan ile olan hava sahası sorunu sonucunda Rusya'nın agresif tutumu tüm dünya tarafından tepki toplamış, ilgili tarih aralıkları incelendiğinde ABD'nin, NATO ile birlikte Gürcistan'da askeri tatbikat kararı aldığı belirlenmiştir. İlgili getiriler üzerinde bu durumun etkili olabileceği düşünülmektedir. G.Afrika'da ise 16.07.2009 tarihli olayda (t-3) gününde $\% 10$ hata payıyla anlamlı $\% 2,1$ oranında anormal getiri tespit edilmiştir.

Tablo 6'da 2008 sonrası dönemde not azalışlarına ait istatistiki olarak anlamlı anormal getiri oranları sunulmuştur. 
Tablo 6. 2008 Sonrası Dönem Not Azalıșlarına Ait AR Tablosu $(-15 ;+15)$

\begin{tabular}{|c|c|c|c|c|c|c|c|c|c|c|c|c|c|c|c|}
\hline Ülke & \multicolumn{3}{|c|}{ Türkiye } & \multicolumn{4}{|c|}{ Brezilya } & \multicolumn{2}{|c|}{ Rusya } & Çin & \multicolumn{5}{|c|}{ G.Afrika } \\
\hline $\begin{array}{l}\text { Olay } \\
\text { Tarihi } \\
\text { Olay } \\
\text { Penceres } \\
\text { i }\end{array}$ & $\begin{array}{c}20.07 \\
. \\
2016\end{array}$ & $\begin{array}{c}27.0 \\
1 . \\
2017\end{array}$ & $\begin{array}{c}07.0 \\
3 . \\
201 \\
8\end{array}$ & $\begin{array}{c}24 . \\
03 . \\
201 \\
4\end{array}$ & $\begin{array}{c}11 . \\
08 . \\
201 \\
5\end{array}$ & $\begin{array}{c}17.0 \\
2 . \\
201 \\
6\end{array}$ & $\begin{array}{c}11.0 \\
1 . \\
201 \\
8\end{array}$ & $\begin{array}{c}08 . \\
12 . \\
200 \\
8\end{array}$ & $\begin{array}{l}25 . \\
04 . \\
20 \\
14\end{array}$ & $\begin{array}{c}24.05 \\
\cdot \\
2017\end{array}$ & $\begin{array}{l}27 . \\
09 . \\
20 \\
12\end{array}$ & $\begin{array}{l}13 . \\
06 . \\
20 \\
14\end{array}$ & $\begin{array}{c}04.12 \\
\cdot \\
2015\end{array}$ & $\begin{array}{l}03.0 \\
4 . \\
201 \\
7\end{array}$ & $\begin{array}{c}24.1 \\
1 . \\
201 \\
7\end{array}$ \\
\hline $\mathbf{A R}(-15)$ & & & $\begin{array}{l}- \\
0,01 \\
88 *\end{array}$ & & & & & & & & & & & & \\
\hline AR(-14) & & & & & & & & $\begin{array}{l}0,0 \\
87 * \\
*\end{array}$ & $\begin{array}{l}- \\
0,0 \\
24 \\
*\end{array}$ & & $\begin{array}{l}0,0 \\
11 \\
* *\end{array}$ & & & & \\
\hline AR(-13) & & & & & & & & & & & $\begin{array}{l}- \\
0,0 \\
09 \\
*\end{array}$ & & & & \\
\hline $\operatorname{AR}(-12)$ & & & & & & & $\begin{array}{l}0,02 \\
2 * *\end{array}$ & & & & & & & & \\
\hline $\operatorname{AR}(-11)$ & & $\begin{array}{l}0,03 \\
17 * * \\
*\end{array}$ & $\begin{array}{l}- \\
0,01 \\
84 *\end{array}$ & & $\begin{array}{l}0,0 \\
242 \\
*\end{array}$ & & & & & & & & & & \\
\hline $\operatorname{AR}(-10)$ & & & $\begin{array}{l}0,0 \\
184 \\
*\end{array}$ & & & $\begin{array}{l}0,01 \\
8^{*}\end{array}$ & & $\begin{array}{l}0,1 \\
03 * \\
* *\end{array}$ & & & & & & & \\
\hline $\operatorname{AR}(-9)$ & & & & & $\begin{array}{l} \\
0,0 \\
34^{*} \\
* *\end{array}$ & & & & & & & & & & \\
\hline $\operatorname{AR}(-8)$ & & & & & $\begin{array}{l}0,0 \\
33 * \\
* *\end{array}$ & & & $\begin{array}{l}- \\
0,0 \\
64 *\end{array}$ & & & & & & & \\
\hline $\operatorname{AR}(-6)$ & $\begin{array}{c}0,01 \\
87^{*}\end{array}$ & & & & & & & & & & & & & & \\
\hline $\mathbf{A R}(-3)$ & & & & & & & & & & & $\begin{array}{l}- \\
0,0 \\
09\end{array}$ & & & & \\
\hline $\operatorname{AR}(-2)$ & $\begin{array}{l}- \\
0,074 \\
7 * * *\end{array}$ & $\begin{array}{l}- \\
0,01 \\
61^{*}\end{array}$ & & $\begin{array}{l}0,0 \\
23 * \\
*\end{array}$ & & $\begin{array}{l}0,02 \\
9 * * \\
*\end{array}$ & & & & & & & & & $\begin{array}{l}- \\
0,01 \\
0 * *\end{array}$ \\
\hline $\operatorname{AR}(-1)$ & & & & & & & & & & & $\begin{array}{l}- \\
0,0 \\
11 \\
* *\end{array}$ & & & & \\
\hline $\mathbf{A R}(\mathbf{0})$ & $\begin{array}{l}- \\
0,018 \\
9 *\end{array}$ & & & & & & & & & & & & $\begin{array}{l}- \\
0,018 \\
* *\end{array}$ & & \\
\hline $\mathbf{A R}(1)$ & $\begin{array}{l}- \\
0,044 \\
9 * * *\end{array}$ & $\begin{array}{l}0,02 \\
99 * * \\
*\end{array}$ & & & & & & & & $\begin{array}{l}0,012 \\
* *\end{array}$ & & & & & \\
\hline $\mathbf{A R}(2)$ & & & & & & & & & & & $\begin{array}{l}0,0 \\
12 \\
* *\end{array}$ & & & & \\
\hline $\mathbf{A R}(3)$ & $\begin{array}{l}0,03 \\
36 * * \\
*\end{array}$ & & & $\begin{array}{l}0,0 \\
30 * \\
* *\end{array}$ & $\begin{array}{l}0,0 \\
32 * \\
*\end{array}$ & & & & & & & & & & $\begin{array}{l}0,00 \\
8^{*}\end{array}$ \\
\hline
\end{tabular}




\begin{tabular}{|c|c|c|c|c|c|c|c|c|c|c|c|}
\hline $\operatorname{AR}(6)$ & $\begin{array}{l}- \\
0,01 \\
57^{*}\end{array}$ & & & & & & & & & & \\
\hline $\mathbf{A R}(7)$ & & $\begin{array}{l}0,0 \\
26^{*} \\
*\end{array}$ & & & & & $\begin{array}{l}0,0 \\
32 \\
* *\end{array}$ & & & & $\begin{array}{l}- \\
0,00 \\
8^{*}\end{array}$ \\
\hline $\operatorname{AR}(8)$ & & & $\begin{array}{l}0,0 \\
29 * \\
*\end{array}$ & & $\begin{array}{l}- \\
0,01 \\
9 * *\end{array}$ & & & $\begin{array}{l}0,012 \\
* *\end{array}$ & & & \\
\hline $\operatorname{AR}(9)$ & & & & & $\begin{array}{l}0,03 \\
2 * * \\
* \\
\end{array}$ & & & & & $\begin{array}{l}- \\
0,01 \\
2 * *\end{array}$ & \\
\hline $\mathbf{A R}(10)$ & $\begin{array}{l}- \\
0,01 \\
94 * *\end{array}$ & $\begin{array}{l}0,0 \\
20^{*}\end{array}$ & & & & $\begin{array}{l}0,0 \\
72^{*} \\
* \\
\end{array}$ & & & & & \\
\hline $\mathbf{A R}(11)$ & & & $\begin{array}{l}0,0 \\
39 * \\
* *\end{array}$ & $\begin{array}{l}0,03 \\
4 * * \\
*\end{array}$ & & $\begin{array}{l}0,0 \\
69 * \\
*\end{array}$ & & & \begin{tabular}{|l}
0,0 \\
09 \\
$*$
\end{tabular} & & \\
\hline $\mathbf{A R}(12)$ & & & $\begin{array}{l}0,0 \\
29 *\end{array}$ & & & & & & & & \\
\hline $\mathbf{A R}(13)$ & & & & $\begin{array}{l}- \\
0,01 \\
9^{*}\end{array}$ & & & & & & & \\
\hline $\mathbf{A R}(14)$ & & $\begin{array}{l}0,0 \\
20^{*}\end{array}$ & & & & & & & & & \\
\hline
\end{tabular}

Tablo 6'da görüleceği üzere T-BRICS ülkeleri arasında sadece Hindistan'a ait istatistiki olarak anlamlı AR tespit edilememiştir. Kalan beş ülkeye ait toplamda 52 adet AR tespit edilen bu dönemde ilgili getirilerin 23'ü olaydan önce, 29'u ise olay günü ve sonrası dönemde gerçekleşmiştir. Olay öncesi gerçekleşen getirilerin 10 tanesinin negatif olduğu tespit edilmiştir.

Türkiye'de 20.07.2016 tarihli olayda (t-6), (t-2), (t0), (t+1), (t+3) günlerinde anormal getiriler tespit edilmiştir. Her ne kadar olumsuz bir not duyurusu öncesinde piyasada meydana gelen negatif anormal bir getiri gibi görülse de ilgili tarih, Türkiye'de askeri darbe girişiminin olduğu 15.07.2016'dan sonraki ilk işlem günüdür. İlgili anormal getirinin not duyurusundan ziyade bu gelişmeden etkilendiği düşünülmektedir. 27.01.2017 tarihli olayda, (t-11), (t-2), $(t+1),(t+6)$ ve $(t+9)$ günlerinde anormal getiri tespit edilmiştir. Bir diğer olay tarihi olan 07.03.2018 tarihinde (t-15), (t-11) ve (t-10) günlerinde anormal getiri meydana gelmiştir. Türkiye için bu üç olay incelendiğinde olay tarihinden önce 7 adet, olay tarihi ve sonrasında ise 6 adet anormal getiri tespit edilmiştir. $\mathrm{Bu}$ anormal getirilerin 8 tanesinin negatif olduğu bunlardan 3 tanesinin olay sonrasında kalan 5 tanesinin ise olay öncesinde meydana geldiği görülmektedir. Olumsuz bir olay öncesinde negatif anormal getirilerin elde edilmesi piyasada bilgi sızıntısı olabileceği ihtimalini güçlendirmektedir. Bu durum Türkiye hisse senedi piyasasının yarı etkin formda etkin olmadığı şeklinde yorumlanabilir.

Brezilya'da not azalışlarının genellikle pozitif anormal getiriye yol açtığ 1 görülmektedir. 24.03.2014 tarihli olayda $(\mathrm{t}-2),(\mathrm{t}+3),(\mathrm{t}+7),(\mathrm{t}+10)$ ve $(\mathrm{t}+14)$ günlerinde tüm anormal getirilerin pozitif yönlü olduğu tespit edilmiştir. 11.08.2015 tarihli olayda $(\mathrm{t}-11),(\mathrm{t}-9),(\mathrm{t}-8),(\mathrm{t}+3),(\mathrm{t}+8),(\mathrm{t}+11)$ ve $(\mathrm{t}+12)$ 
günlerinde anormal getiri tespit edilmiş, anormal getiriler arasında sadece (t-9) gününde negatif yönlü olduğu bulgulanmıştır. 17.02.2016 tarihli olayda $(\mathrm{t}-10)$, (t$2),(t+11)$ ve $(t+13)$ günlerinde anormal getiri tespit edilmiştir. Son olarak 11.01.2018 tarihli olayda, $(\mathrm{t}-12),(\mathrm{t}+8)$ ve $(\mathrm{t}+9)$ günlerinde anormal getiri tespit edilmiştir. Brezilya'da 2008 sonrası dönemde not düşüş olaylarının öncesi ve sonrasında tespit edilen anormal getirilerin büyük çoğunluğunun pozitif olduğu görülmektedir.

Rusya'da 08.12.2008 tarihli olayda, (t-14), (t-10), (t-8), (t+10) ve (t+11) günlerinde anormal getiriler tespit edilmiştir. Rusya için diğer olay tarihi olan 25.04.2014'te ise ( $(\mathrm{t}-14)$ ve $(\mathrm{t}+7)$ günlerinde anormal getiri tespit edilmiştir.

Çin'de 24.05.2017 tarihli olayda $(\mathrm{t}+1)$ ve $(\mathrm{t}+8)$ günlerinde pozitif anormal getiri tespit edilmiştir. Olay öncesinde herhangi bir anormal getirinin tespit edilmemesinden dolayı Çin piyasasının ilgili olay öncesinde etkin özellik gösterdiği yorumu yapılabilir.

G.Afrika'da 27.09.2012 tarihli olayda (t-13), (t-3) ve (t-1) günlerinde negatif anormal getiriye rastlanmıştır. 13.06.2014 tarihli olayda $(t+11)$. günde anormal getiri tespit edilmiştir. 14.12.2015 tarihli olayda (t0)' da \%-1,8 anormal getiri, 03.04.2017 $(t+9)$. günde negatif anormal getiri ve son olarak 24.11.2017 tarihli olayda (t-2) gününde negatif anormal getiri tespit edilmiştir. Tüm olaylar incelendiğinde olay tarihinden önce negatif anormal getirilerin tespiti, bilgi sızıntısının olabileceği ihtimalini arttırdığı için bu durum G.Afrika hisse senedi piyasasının yarı etkin formda etkin olmadığı şeklinde yorumlanabilir.

Tablo 6'da yer alan olay günü ve sonrasında gerçekleşen anormal getirilere bakıldığında toplam yirmi dokuz adet olan bu getirilerden sadece yedi tanesinin negatif anormal getiri olduğu görülmektedir. Bu durum, negatif bir olay sonrasında hisse senedi piyasalarında beklentinin bitmiş olduğunu ve yatırımcıların alım yapmaya başladıklarının bir göstergesi olarak yorumlanabilir.

2008 öncesi dönem not artışına ait anlamlı CAR değerleri Tablo 7'de sunulmuştur.

Tablo 7. 2008 Öncesi Dönemde Gerçekleşen Not Artışına Ait CAR Değerleri

\begin{tabular}{|c|c|c|c|c|}
\hline Ülke & Olay Penceresi & Olay & Olay Tarihi & CAR \\
\hline Rusya & $(-10 ; 10)$ & Not Artış1 & 18.11 .2004 & $-0,1834 *$ \\
\hline Rusya & $(-15 ; 15)$ & Not Artış1 & 18.11.2004 & $-0,2901 * *$ \\
\hline Hindistan & $(-1 ; 1)$ & Not Artış1 & 21.01 .2004 & $-0,1029 * * *$ \\
\hline Hindistan & $(-5 ; 5)$ & Not Artış1 & 21.01 .2004 & $-0,087 *$ \\
\hline Hindistan & $(-10 ; 10)$ & Not Artış1 & 21.01 .2004 & $-0,1145^{*}$ \\
\hline Çin & $(-1 ; 1)$ & Not Artış1 & 17.02 .2004 & $0,032 *$ \\
\hline Çin & $(-10 ; 10)$ & Not Artıș1 & 27.07 .2006 & $-0,1448 * *$ \\
\hline Çin & $(-15 ; 15)$ & Not Artış1 & 27.07 .2006 & $-0,1676^{* *}$ \\
\hline Çin & $(-1 ; 1)$ & Not Artışı & 26.07 .2007 & $0,0759^{*}$ \\
\hline Çin & $(-5 ; 5)$ & Not Artış1 & 26.07.2007 & $0,1373^{*}$ \\
\hline Cin & $(-10 ; 10)$ & Not Artıs1 & 26.07 .2007 & $0,208^{*}$ \\
\hline Çin & $(-15 ; 15)$ & Not Artıș1 & 26.07 .2007 & $0,2895 * *$ \\
\hline \multicolumn{5}{|c|}{ *: \%10 Hata oranında anlamlı $\quad$ ***: \%1 Hata oranında anlamlı } \\
\hline
\end{tabular}


Tablo 7 incelendiğinde CAR değerlerinin genel olarak negatif yönlü oldukları görülmektedir. İlgili piyasalarda tespit edilen toplam on iki adet CAR değerinin yedisi negatif yönde gerçekleşmiştir. Türkiye, Brezilya ve G.Afrika piyasaları için anlamlı CAR değerleri tespit edilememiştir.

Hindistan' da 21.01.2004 olay tarihinde $(-1 ;+1)$ aralığında \%1 hata payıla \%-10,29 oranında CAR tespit edilmiştir. İlgili olay derecelendirme duyurularından bağımsız gelişmelerden etkilendiği için kirlenmiş olay olarak kabul edilmiştir.

2008 sonrası dönem not artışına ait anlamlı CAR değerleri Tablo 8'de sunulmuştur.

Tablo 8. 2008 Sonrası Dönemde Gerçekleşen Not Artışına Ait CAR Değerleri

\begin{tabular}{|c|c|c|c|c|}
\hline Ülke & Olay Penceresi & Olay & Olay Tarihi & CAR \\
\hline Türkiye & $(-1 ;+1)$ & Not Artış1 & 03.12 .2009 & $0,0732^{* * *}$ \\
\hline Türkiye & $(-5 ;+5)$ & Not Artış1 & 03.12 .2009 & $0,0725^{*}$ \\
\hline Türkiye & $(-1 ;+1)$ & Not Artış1 & 20.06 .2012 & $0,0348^{*}$ \\
\hline Türkiye & $(-15 ;+15)$ & Not Artış1 & 20.06 .2012 & $0,0979^{*}$ \\
\hline Rusya & $(-15 ;+15)$ & Not Artış1 & 16.07 .2008 & $-0,1594^{*}$ \\
\hline Rusya & $(-1 ;+1)$ & Not Artış1 & 23.02 .2018 & $0,0237^{* *}$ \\
\hline $\begin{array}{l}*: \% \text { 10 Hata oranında anlamlı } \% \text { Hata oranında anlamlı } \\
\text { **: \%5 Hata oranında anlamlı }\end{array}$ &
\end{tabular}

Tablo 8'deki CAR değerleri incelendiğinde, Türkiye'de gerçekleşen 03.12.2009 tarihli olayda $(-1 ;+1)$ aralığında $\% 1$ hata payıyla $\% 7,32$ oranında CAR tespit edilmiştir. Aynı olay tarihinde $(-5 ;+5)$ aralığında $\% 10$ hata payıyla \%7,25'lik bir kümülatif anormal getiri meydana geldiği görülmektedir.

20.06.2012 tarihli olayda $(-10 ;+10)$ aralığında $\% 10$ hata payıla $\% 10,18$ oranında kümülatif anormal getiri tespit edilmiştir. Aynı olay tarihinde $(-15 ;+15)$ aralığında gerçekleşen kümülatif anormal getiri \%9,79 olarak bulunmuştur.

Brezilya, Hindistan, Çin ve G.Afrika piyasaları için anlamlı CAR değerleri tespit edilememiştir.

Rusya için 16.07.2008 tarihli olayda $(-15 ;+15)$ aralığında negatif yönde CAR bulgulanmıştır. İlgili olay derecelendirme duyurularından bağımsız gelişmelerden etkilendiği için kirlenmiş olay olarak kabul edilmiştir. 23.02.2018 tarihinde Rusya'da gerçekleşen bir diğer not artış olayı ise $(-1 ;+1)$ aralığında \%5 hata payıyla \%2,37 oranında kümülatif anormal getiriye sebep olmuştur.

2008 sonrası dönemde gerçekleşen not azalışına ait CAR değerleri Tablo 9'da sunulmuştur.

Tablo 9. 2008 Sonrası Dönemde Gerçekleşen Not Azalışına Ait CAR Değerleri

\begin{tabular}{|c|c|l|l|l|}
\hline Brezilya & $(-5 ;+5)$ & Not Düşüşü & 24.03 .2014 & $0,0844 * *$ \\
\hline Brezilya & $(-10 ;+10)$ & Not Düşüşü & 24.03 .2014 & $-0,1158 * *$ \\
\hline Brezilya & $(-15 ;+15)$ & Not Düşüşü & 17.02 .2016 & $0,1691 * *$ \\
\hline Çin & $(-15 ;+15)$ & Not Düşüşü & 24.05 .2017 & $0,0651^{*}$ \\
\hline $\begin{array}{l}*: \% \text { \% Hata oranında anlamlı \%1 Hata oranında anlamlı } \\
\text { **: \%5 Hata oranında anlamlı }\end{array}$ &
\end{tabular}

Tablo 9'daki CAR değerleri incelendiğinde 24.03.2014 tarihli olayda ($10 ;+10)$ aralığında $\% 5$ hata payıyla $-\% 11,58$ oranında kümülatif anormal getiri tespit edilmiştir. Negatif bir olayla aynı yönlü gerçekleşen bir getiri olmasına 
rağmen $(-5 ;+5)$ aralığında Brezilya'da $\% 5$ hata payıyla $\% 8,44$ oranında kümülatif anormal getirinin meydana geldiği tespit edilmiştir. Bu not düşürme duyurusunun piyasa üzerinde olumsuz etkiye sebep olması beklenirken pozitif getirinin tespit edilmesi, piyasanın başka bir olaydan etkilenmesi ihtimalini akla getirmiştir. Yapılan araştırmalar sonucunda 2014 Dünya kupasının Brezilya'da oynanacak olmasının ekonomiye olumlu yansıdığı tespit edilmiştir. Bahsi geçen bu getirinin, ilgili gelişmeden kaynaklanabileceği düşünülmektedir. 17.02.2016 tarihli olayda $(-15 ;+15)$ aralığında $\% 16,91$ oranında kümülatif anormal getiri tespit edilmiştir. Yapılan araştırmalar sonucunda bu getirinin Brezilya'nın terörle mücadelede büyük gelişme kaydettiği ve aynı zamanda ekonomik açıdan gelişmekte olan ülkeler arasında ihracat performansı ve doğal kaynakların doğru kullanımı konularında kamuoyundan olumlu tepkiler aldığı tespit edilmiştir. Bahsi geçen bu olayların CAR üzerinde etkisinin olabileceği düşünülmektedir. Son olarak Çin'de meydana gelen 24.05 .2017 tarihli olayda, $(-15 ;+15)$ aralığında $\% 6,51$ kümülatif anormal getiri tespit edilmiştir. verilmiştir.

Tüm derecelendirme not duyurularına ait AAR değerleri Tablo 10'da

Tablo 10. 2008 Öncesi ve 2008 Sonrası Dönem AAR Değerleri

\begin{tabular}{|c|c|c|c|}
\hline \multirow[t]{2}{*}{ Gün } & \multirow{2}{*}{$\begin{array}{c}2008 \text { Öncesi } \\
\text { Not Artış }\end{array}$} & \multicolumn{2}{|c|}{2008 Sonrası } \\
\hline & & Not Artış & Not Azalış \\
\hline AAR(-13) & & $0,006 * *$ & \\
\hline $\operatorname{AAR}(-12)$ & & $-0,0039 *$ & \\
\hline AAR(-10) & & $-0,0055^{*}$ & \\
\hline AAR (-7) & & & $0,0029^{*}$ \\
\hline AAR (-4) & & $0,0035^{* *}$ & \\
\hline AAR (3) & & $-0,0064 * *$ & $0,007 * *$ \\
\hline AAR (4) & $-0,0079 * * *$ & & \\
\hline AAR (5) & $0,0061 * *$ & & \\
\hline AAR (7) & & $-0,009^{*}$ & \\
\hline AAR(11) & & & $0,0093^{*}$ \\
\hline AAR(13) & $0,0053 * *$ & & \\
\hline
\end{tabular}

Tablo 10 incelendiğinde 2008 öncesi not artışına ait olay günü öncesinde anlamlı AAR tespit edilememiştir. $(t+4)$. günde en düşük seviyeye gelen \%-0,79 ortalama anormal getiri $\% 1$ hata payıyla anlamlıdır. AAR, $(\mathrm{t}+5)$. günde ise en yüksek seviye olarak $\% 0,61$ oranında $\% 5$ hata payıla anlamlıdır. AAR, $(\mathrm{t}+13)$. günde $\% 5$ hata payıyla $\% 0,53$ olarak tespit edilmiştir.

2008 sonrası dönemde gerçekleşen not artışı olaylarına ait AAR değerlerinin incelenmesi sonucunda $(\mathrm{t}-13)$. günde gerçekleşen $\% 0,6$ oranında AAR, $\% 5$ hata payıyla anlamlıdır. (t-12). günde gerçekleşen AAR değeri \%-0,39 oranında $\% 10$ hata payıyla anlamlıdır. (t-10). günde $\%-0,55$ oranındaki AAR $\% 10$ hata payıla anlamlıdır. Olay öncesi son anlamlı getiri olan (t-4). günde $\% 0,35$ değeri $\% 5$ hata payıyla anlamlıdır. Olaydan sonra tespit edilen anlamlı AAR değerleri ise $(\mathrm{t}+3)$. günde $\% 5$ hata payıla $\%-0,64,(\mathrm{t}+7)$. günde $\% 10$ hata payiyla \%-0,09 oranındadır. Elde edilen bulgular, 2008 krizi sonrası olumlu yönde gerçekleşen ülke kredi derecelendirme not duyurularının olay tarihinden önce TBRICS ülkeleri üzerine etkisinin (t-4). günde yansıdığını göstermektedir. 
2008 sonrası dönemde gerçekleşen not artışı olaylarında ortalama anormal getirilerin incelenmesi sonucunda olay öncesinde ve sonrasinda istatistiki olarak anlamlı negatif AAR rastlanılamamıştır. (t-7). günde \%0,29 oranında \%10 hata payıyla anlamlı ortalama anormal getiri tespit edilmiştir. Olay tarihinden sonra $(t+3)$. günde $\% 5$ hata payıyla $\% 0,07$ oranında, $(t+11)$. günde $\% 10$ hata payıyla \%0,93 oranında AAR tespit edilmiştir.

Kümülatif ortalama anormal getiri (CAAR) değerleri tüm ülkelerin birlikte değerlendirildiği en genel analiz yöntemidir. Bu değerler Tablo 11'de sunulmuştur.

Tablo 11. 2008 Öncesi ve Sonrası Döneme Ait CAAR Değerleri

\begin{tabular}{|l|l|l|l|l|}
\hline \multirow{2}{*}{$\begin{array}{l}\text { Olay Penceresi } \\
\text { Olay }\end{array}$} & $(-1 ;+1)$ & $(-5 ;+5)$ & $(-10 ;+10)$ & $(-15 ;+15)$ \\
\cline { 2 - 5 } & CAAR & CAAR & CAAR & CAAR \\
\hline $\begin{array}{l}\text { 2008 Öncesi } \\
\text { Not Artışı }\end{array}$ & $-0,0046$ & $-0,0021$ & $-0,0125$ & $-0,0093$ \\
\hline $\begin{array}{l}\text { 2008 Sonrası } \\
\text { Not Artıs }\end{array}$ & 0,0112 & 0,0091 & $-0,0117$ & $-0,0007$ \\
\hline $\begin{array}{l}\text { 2008 Sonrası } \\
\text { Not Düşüş }\end{array}$ & $-0,0033$ & 0,0003 & 0,0145 & $0,0226^{*}$ \\
\hline \multirow{2}{*}{$* \% 10$ Hata oranında anlamlı } & & \multicolumn{4}{|l}{} \\
\hline
\end{tabular}

Tablo 11 incelendiğinde 2008 sonrası dönemde gerçekleşen not düşüşlerinde $(-15 ;+15)$ aralığında anlamlı CAAR rastlanmaktadır. Özellikle olay günü çevresini daha yakından kapsayan $(-1,+1)$ ve $(-5,+5)$ olay pencereleri ile 2008 öncesi ve sonrası meydana gelen not artışlarında anlamlı herhangi bir CAAR rastlanmamıştır. Bu durum T-BRICS ülkelerinin benzer olaylar karşısında genelleme yapılabilecek benzer tepkiler vermediğini göstermektedir.

\section{SONUÇ}

$\mathrm{Bu}$ çalışmada Moody's, S\&P ve Fitch derecelendirme kuruluşları tarafından 2004-2019 yılları arasında T-BRICS ülkeleri hakkında yapmış oldukları derecelendirme not açıklamalarının hisse senedi piyasalarını etkileyip etkilemediği araştırılmıştır. Yapılan analiz sonucunda olay günleri, olayın türüne göre gerçekleşen anormal getiriler tespit edilmiştir. Bu durum derecelendirme not duyurularının hisse senedi piyasalarında yeni bir bilgi değeri sunduğunun göstergesidir. Analiz sonucunda 2008 öncesi dönemde Türkiye'de, 2008 sonrası dönemde Türkiye, Brezilya ve G.Afrika'da olay günlerinde açıklamanın türüne göre negatif ya da pozitif anormal getiri tespit edilmiştir. Bu bulgular Goh \& Louis (1993) çalışmalarına göre farklılık göstermektedir.

2008 sonrası dönemde not azalış duyuruları incelendiğinde, bu duyuruların Brezilya'da pozitif anormal getirilere neden olduğu tespit edilmiştir. Bu bulgular Ferreira \& Gama (2007) ile Alsakka ve Gwilym (2012) bulgulariyla aynı yönde olup, coğrafi mesafenin ülkelerin aynı tür olaylara farklı tepkiler verebilmesine neden olabileceği şeklinde yorumlanmıştır.

2008 sonrası dönemde not artış duyurularının, olay tarihinden önce tüm ülke piyasalarında istatistiki olarak anlamlı anormal getirilere yol açtığı tespit edilmiştir. Bu sonuçlar, çalışmalarında sadece not azalışlarının anormal getirilere neden olduğunu, not artışlarının anlamlı etkisinin bulunmadığını tespit eden Griffin ve Sanvicente (1982), Brooks vd. (2004) ve Bheenick (2004)'e göre 
farklı1ık göstermektedir. 2008 sonrası dönemde not artış duyurularının bazı ülkelerde negatif anormal getirilere yol açmasının nedeni Mortgage krizi sonrası gelişmekte olan ülke piyasalarında görülen dış şoklara karşı kırılganlık ve sıçrama etkilerinden kaynaklanabileceği düşünülmektedir.

Hindistan ve Çin hisse senedi piyasalarında, 2008 sonrası dönemde gerçekleşen not düşüş olaylarına ait herhangi bir anlamlı anormal getiri tespit edilememiştir. Dolayısıyla bu durum, not düşüş olaylarında ilgili piyasaların etkin özellikte olduğu şeklinde yorumlanabilir. Elde edilen bu bulgular Yıldırım, Yıldız ve Aydemir (2018) ile aynı yönde olup, derecelendirme notlarının tüm hisse senedi piyasalarını etkilemediği sonucuna ulaşılmıştır.

Araştırma sonucunda bazı ülkelerde not açıklamaları öncesinde duyurunun yönüyle aynı yönde anormal getirilerin gerçekleştiği tespit edilmiştir. Elde edilen bulgular Hooper, Hume ve Kim (2008) tarafından gerçekleştirilen çalışmayla aynı yönlü olup derecelendirme not açılamalarından önce ilgili piyasalarda bilgi sızıntısının var olduğu, derecelendirme duyurularının bazı ülkelerin hisse senedi piyasalarında bilgi değerinin olduğu ve piyasaların yarı etkin özellikte olmadığı sonucuna ulaşılmıştır. Bu sonuçtan hareketle H0 hipotezi reddedilmiştir.

AAR değerleri incelendiğinde Paterson ve Gauthier (2013)'in aksine, 2008 öncesi dönem not artışlarında $(\mathrm{t}+4),(\mathrm{t}+5),(\mathrm{t}+13)$ günlerinde, 2008 sonrası dönem not düşüşlerinde $(\mathrm{t}-7),(\mathrm{t}+3),(\mathrm{t}+11)$ günlerinde, 2008 sonrası dönem not artış olaylarında ise (t-13), (t-12), (t-10), $(\mathrm{t}-4),(\mathrm{t}+3)$ ve $(\mathrm{t}+7)$ günlerinde istatistiki olarak anlamlı ortalama anormal getirilere yol açtığ tespit edilmiştir.

CAAR değerleri incelendiğinde ise $(-15 ;+15)$ olay penceresinde sadece 2008 sonrası not düşüş olaylarına T-BRICS ülkelerinin benzer yönde tepki verdiği diğer tüm olay pencereleri ve olay türlerinde ilgili ülkelerin benzer olaylar karşısında genelleme yapılabilecek benzer tepkiler vermediği tespit edilmiştir.

$\mathrm{Bu}$ çalışmada KDK'lar tarafından yayınlanan ülke derecelendirme not duyurularının T-BRICS hisse senedi piyasaları üzerine etkisi günlük borsa kapanış değerleriyle incelenmiştir. Derecelendirme not duyurularının hisse senedi piyasaları üzerine etkisinin değerlendirilmesinde olay penceresinin daha kısa bir süreyi (saat, dakika) kapsamasının da literatüre katkı sağlayacağ düşünülmektedir.

\section{KAYNAKÇA}

Alexander, C. (2001). Market Models: A Guide to Financial Data Analysis. Chichester: John Wiley $\&$ Sons Ltd.

Alexander, C., \& Thillainathan, R. (1995). The Asian connections. Emerging Markets Investor, 2(6), 42-46.

Alsakka, R., \& Gwilym, O. a. (2012). Foreign exchange market reactions to sovereign credit news. Journal of International Money and Finance, 845-864.

Ashley, J. W. (1962). Stock Prices and Changes in Earnings and Dividends: Some Empirical Results. Journal of Political Economy, 70(1), 82-85.

Ball, R., \& Brown, P. (1968). An Empirical Evaluation of Accounting Income Numbers. Journal Accounting Research, 6(2), 159-178.

Barker, C. A. (1956). Effective Stock Splits. Harvard Business Review, 101-106.

Barker, C. A. (1957). Stock Splits in a Bull Market. Harvard Business Review, 35(3), 72-79.

Barker, C. A. (1958). Evaluation of Stock Dividends. Harvard Business Review, 36(4), 99-114. 
Musa Ovalı \& Turan Kocablyık \& Umut Burak Geyikçi / Kredi Derecelendirmenin Borsa Endeksleri Üzerindeki Etkileri: T-BRICS Ülkeleri Üzerine Bir Araştırma

Bheenick, E. B. (2004). Rating timing differences between the two leading agencies: Standard and Poor's and Moody's. Emerging Markets Review, 5(3), 361-378.

Binder, J. (1998). The Event Study Methodology Since 1969. Review of Quantitative Finance and Accounting, 11(2), 111-137.

Brooks, R., Faff, R. W., Hillier, D., \& Hillier, J. (2004). The national market impact of sovereign rating changes. Journal of Banking \& Finance(28), 233-250.

Brown, S. J., \& Warner, J. B. (1985). Using Daily Stock Returns. Journal of Financial Economics, 3-31.

Campbell, C. J., Cowan, A. R. ve Salotti, V. (2010). Multi-country event-study methods. Journal of Banking \& Finance, 34(12), 3078-3090.

Cartony, F. (1999). The Siskel and Ebert of financial markets: Two thumbs down for the credit rating agencies. Washington University Law Quarterly, 77, 619-712.

Chung, P. J., \& Liu, D. J. (1994). Common stochastic trends in Pacific rim stock markets. Quarterly Review of Economics and Finance, 34(3), 241-259.

Clay, J. D. (1933). Characteristics and Procedure of Common Stock Split-Ups. Harvard Business Review (11), 316-26.

Click, R., \& Plummer, M. (2005). Stock market integration in ASEAN after the Asian financial crisis. Journal of Asian Economics, 16(1), 5-28.

Committee on Banking, Housing, and Urban Affairs United States Senate. (2008, Nisan 22). Turmoil in U.S. Credit Markets: The Role of Credit Rating Agencies. Washington.

Correa, R., Lee, K. H., Sapriza, H., \& Suarez, G. (2014). Sovereign credit risk, banks' government support, and bank stock returns around the world. Journal of Money, Credit and Banking(46), 93-121.

Coşkun, Y. (2018). Event Study Investigation: The Impact of Credit Rating on Index Returns. Journal of Current Researches on Business and Economics, 8(2), 31-52.

Dickev, I. D., \& Piotroski, J. D. (2002). The Long-Run Stock Returns Following Bond Ratings Changes. The Journal of Finance(56), 173-203.

Dyckman, T., Philbrick, D., \& Stephan, J. (1984). A Comparison of Event Study Methodologies Using Daily Stock Returns: A Simulation Approach. Journal of Accounting Research, 22, $1-30$.

Ederington, L. H., Yawitz, J. B., \& Roberts, B. E. (1987). The Informal Content of Bond Ratings. Journal of Financial Research, 10(3), 211-226.

Eugene Fama vd. (1969). The Adjustment of Stock Prices to New Information. International Economic Review, 10(1), 1-21.

Ferreira, M. A., \& Gama, P. M. (2007). Does sovereign debt ratings news spill over to international stock markets? Journal of Banking \& Finance, 3162-3182.

Geyikçi, U. B., \& Karğın, M. (2014). Reel Sektör Firmalarına Yönelik Kredi Derecelendirme Model Önerisi. Yönetim ve Ekonomi, 21(1), 323-343.

Goh, C. J., \& Louis, H. E. (1993). Is a Bond Rating Downgrade Bad News, Good News or No News for Stockholders. The Journal of Finance, 48(5), 2001-2008.

Griffin, P. A., \& Sanvicente, A. Z. (1982). Common Stock Returns and Rating Changes: A Methodological Comparison. The Journal of Finance, 31(1), 103-119.

Hooper, V., Hume, T., \& Kim, S.-J. (2008). Sovereign rating changes-Do they provide new information for stock markets? Economic Systems(32), 142-166.

Hunt, J. P. (2009). Credit Rating Agencies and the Wordwide Credit Crisi: The Limits of reputation, the Insufficiency of Reform, and a Proposal for Improvement. Columbia Business Law Review, 1-74.

Kaminsky, G., \& Schmukler, S. L. (2002). Emerging Market Instability: Do Sovereign Ratings Affect Country Risk and Stock Returns? World Bank Economic Review, 16(2), 171-195.

Kasa, K. (1992). Common stochastic trends in international stock markets. Journal of Monetary Economics, 29(1), 95-124.

Kenjegaliev, A., Duygun, M., \& Mamedshakhova, D. (2016). Do rating grades convey important information: German evidence? Economic Modelling, 334-344. 
Klimavičienė, A. (2011). Sovereign Credit Rating Announcements and Baltic Stock Markets. Organizations and Markets in Emerging Economies, 2(1(3)), 51-62.

Kocabiyık, T., \& Altunay, M. A. (2008). Artan Rekabet Ortamında KOBI'lerin Sorunları ve Buna İlişkin Bir Araştırma. Marmara Üniversitesi İktisadi ve İdari Bilimler Fakültesi Dergisi, 25(2), 743-761.

Korkmaz, T., Yaman, S., \& Metin, S. (2017). Ülke Kredi Notlarının Pay Getirileri Üzerindeki Etkileri: BİST 30 Endeksi Üzerinde Bir Event Study Analizi. Sosyal Bilimler Metinleri, 171-187.

Kothari, S. P., \& Warner, J. B. (2004). Econometrics of Event Studies. Hollanda: Handbook of Corporate Finance.

Kräussl, R. (2000). Sovereign Credit Ratings and Their Impact on Recent Financial Crises. Frankfurt: Center For Financial Studies.

Liu, P., \& Thakor, A. V. (1984). Interest Yields, Credit Ratings, and Economic Characteristics of State Bonds: An Empirical Analysis: Note. Journal of Money, Credit and Banking, 344351.

Mackinlay, A. C. (1997). Event Studies in Economics and Finance. Journal of Economic Literature, 35, 13-39.

Martell, R. (2005). The Effect of Sovereign Credit Rating Changes on Emerging Stock Markets. SSRN Electronic Journal.

Myers, J. H., \& Bakay, J. A. (1948). Influence of Stock Split-Ups on Market Price. Harvard Business Review, 251-255.

Park, N. K. (2004). A Guide to Using Event Study Methods in Multi-Country Settings. Strategic Management Journal, 25(7), 655-668.

Oval1, M. (2019). Ülke Kredi Derecelendirmesi Ve Borsa Endeksleri Üzerine Etkisi: T-BRICS Ülkeleri Örneği, Yayınlanmamış Yüksek Lisans Tezi, Süleyman Demirel Üniversitesi, Sosyal Bilimler Enstitüsü, ISPARTA.

Ovalı, M., Kocabıyık, T., \& Geyikçi U.B. (2019). Kredi Derecelendirme ve Borsa İlişkisi. Konya: Eğitim Yayınevi.

Paterson, A., \& Gauthier, D. (2013). Stock Market Impact of Sovereign Credit Rating Announcements: The Case of GIIPS and BRIC countries during the European Sovereign Debt Crisis of 2009-2013. Stockholm, İsveç.

Pinches, G. E., \& Singleton, J. C. (1978). The Adjustment of Stock Prices to Bond Rating Changes. The Journal of Finance, 29-44.

Pirgaip, B. (2017). Derecelendirme Notu Değişikliklerinin Borsa İstanbul(BIST) Pay Piyasası'na Etkileri. Ege Akademik Bakış, 17(3), 351-368.

Pukthuanthong-Le, K., Eayan, F. A., \& Rose, L. C. (2007). Equity and debt market responses to sovereign credit ratings announcement. Global Finance Journal(18), 47-83.

Reisen , H., \& von Maltzan, J. (1998, March/April). Sovereign Credit Ratings, Emerging Market Risk and Financial Market Volatility. Intereconomics, 73-82.

SEC. (2003). Report on the Role and Function of Credit Rating Agencies in the Operation of the Securities Markets. U.S Securities and Exchange Commision.

SPK. (2017, 07 12). Sermaye Piyasasında Derecelendirme Faaliyeti ve Derecelendirme Kuruluşlarına İlişkin Esaslar Tebliği. SPK.

Subaşı, F. O. (2008). The Effect of Sovereign Rating Changes on Stock Returns and Exchange Rates. International Research Journal of Finance and Economics(20), 46-54.

Tan, T. A. (2012). Stock Market Integration: Case of the Philippines. Philippine Management Review, 19, 75-90.

Wilson, D., \& Purushothaman, R. (2003). Dreaming with BRICs: The Path to 2050. New York: Goldman Sachs.

Yıldırım, H. H., Yıldız, C., \& Aydemir, Ö. (2018). Kredi Derecelendirme Kuruluşlarından S\&P, Moody's ve Fitch'in Türkiye için Yapmış Oldukları Not Açıklamalarının Hisse Senedi Endeksleri Üzerine Etkisi: Borsa İstanbul Örneği 2012-2016. Maliye ve Finans Yazllarl, 9-30. 


\section{SUMMARY}

In recent years, globalization has led to an increase in the number of financial instruments and complexity in financial markets. Consequently, serious problems have been encountered in terms of find funding sources and making investment decisions, which have become more and more difficult to achieve their goals for those seeking and offering funds. At this point, both supplier and demander of funds turned to Credit Rating Agencies (CRA) in order to eliminate the problem of asymmetric information and to gain investor confidence. Credit rating is seen as a source of information that facilitates the decision-making process between the fund seekers and the fund offerers.

With the great development of technology, financial markets gain momentum with globalization and global competition increases day by day and so increasing the role of credit ratings in the markets. CRA has ability to continuously monitor institutions that enable to access specific information about issuers of debt instruments. Therefore these organizations have more information advantage than market participants. Because of these characteristics, CRA are organizations with significant impacts on the market. These effects emerge with rapid changes in investors' decisions especially if the rating announcement for a firm or country includes a change in the rating outlook.

The purpose of this study is to determine whether the grade change announcements published by rating agencies have an effect on stock market indices. For this purpose, it will be tried to determine whether the stock market indices belonging to T-BRICS countries are affected by the rating change announcements. The importance of the study emerges from that point, it is important to measure effectiveness of T-BRICS countries' stock markets due to their position in the global economy, population structures, surface areas and the potential to become one of the world's leading economies in the future. The confidence of T-BRICS countries' equity markets towards investors and foreign direct investments will facilitate ease of access to capital and have a very positive impact on acquisition costs.

In this study, sovereign ratings given by S\&P, Moody's and Fitch for T-BRICS countries and the effects of the changes in these grades on the stock markets of the related 6 countries have been examined with the event study method. The period of analysis is determined as 2004-2019. This analysis period is divided into pre-2008 period (2004-2008) and post-2008 period (2008-2019). Countries and stock markets Turkey (BIST 100), Brazil (BOVESPA), Russia (IMPEX), India (NIFTY 50), China (SHANGHAI COMPOSITE) and South Africa (FTSE / JSE All Share) have been determined in research. The CRAs may report different views and grades within a short period of time. This may lead to deviations in abnormal returns to be measured by the event study method used in the study. For the countries examined in the study, it has found that the CRAs made similar announcement ratings in a short period of time. In order to prevent deviations in abnormal returns, the analysis has taken care that at least five months between the rating announcements of all three rating agencies. Due to this 
limitation of the study, no announcement regarding the downgrade in the pre2008 period has been identified.

As a result of the analysis, it has been found that negative (positive) event in the same direction of negative (positive) abnormal return in the stock markets of Turkey, Brazil and South Africa. When the downgrade announcements were examined in the post-2008 period, it was found that these announcements caused positive abnormal returns in Brazil and this result is interpreted that geographical distance could cause countries to react differently to the same kind of events. It is believed that the post-2008 upgrades are causing negative abnormal returns in some countries because of the fragility and jump effects of external shocks in emerging market markets after the Mortgage crisis. It is concluded that there are leakage of information in the relevant markets because of detect abnormal returns in the same direction the announcement before event date. It is concluded that rating announcements have information value in countries' stock markets and markets are not effective in semi-active market form. In addition, it has been found that rating announcements lead to statistically significant AAR, CAR and CAAR returns. 